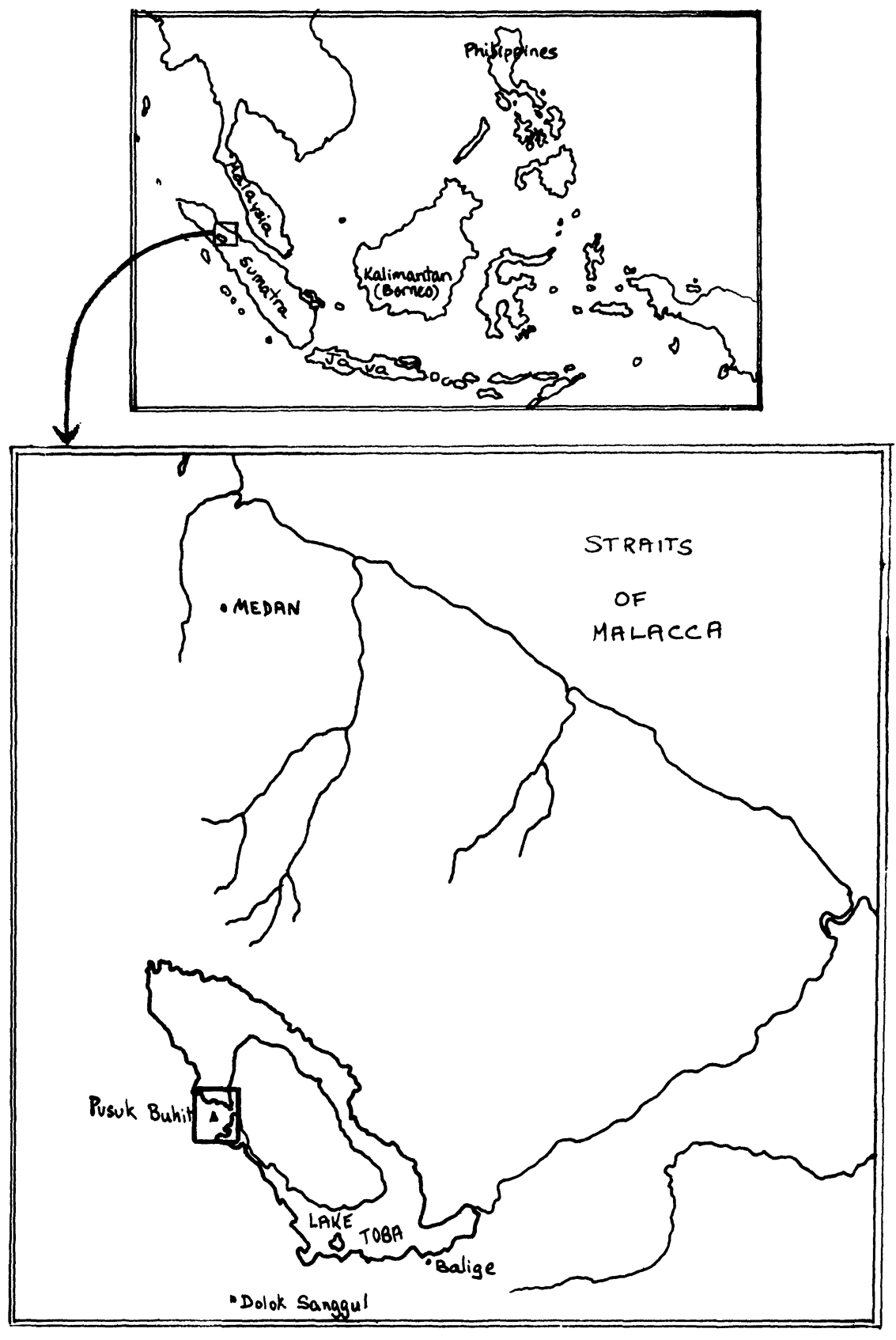

(after a map by the Topografischen dienst [in the KIT] 1933)

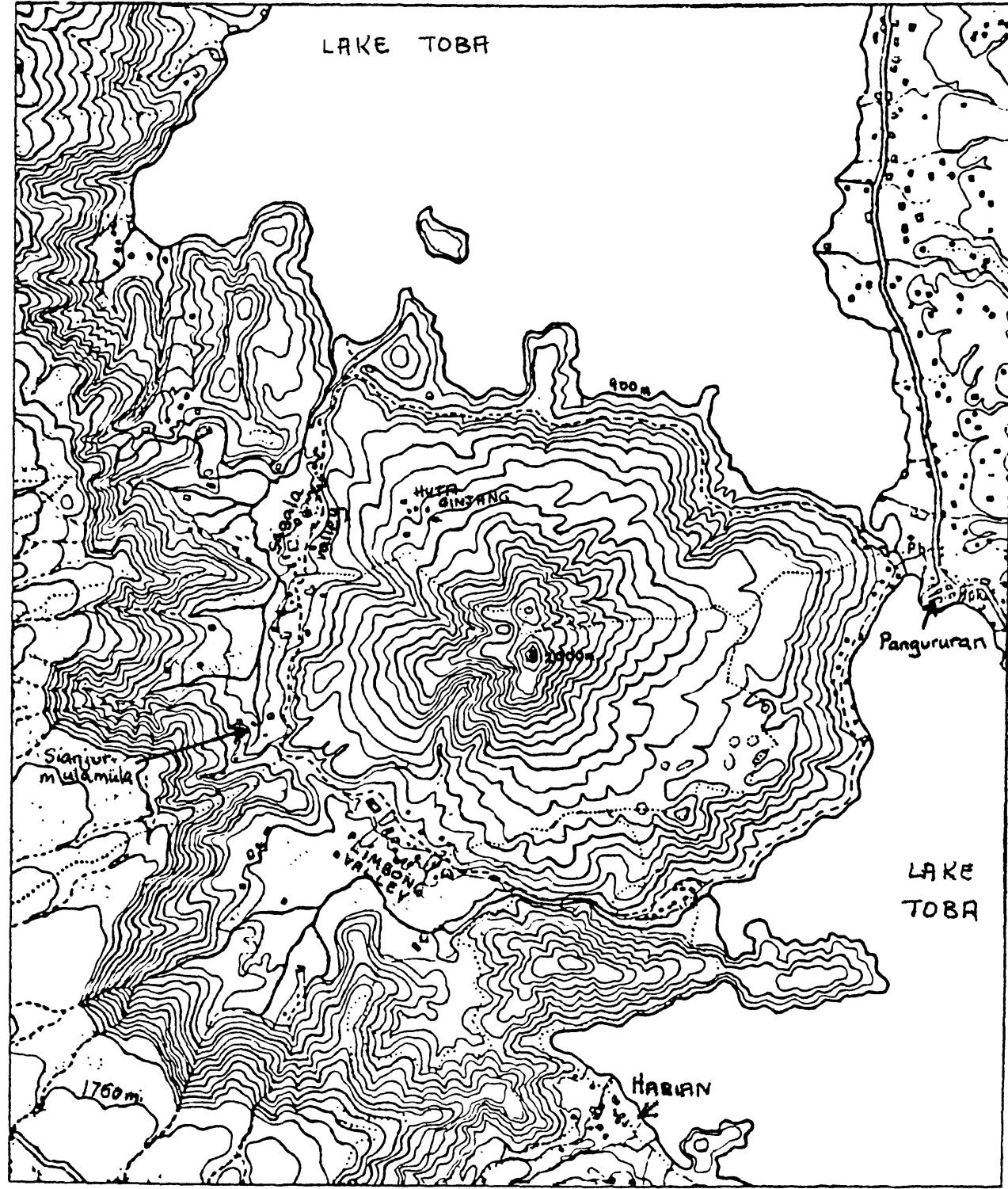

MAP I • LAKE TOBA ANI) MOUNT PUSUK BUHIT 


\section{WHAT "GREEN DESERT"? \\ THE ECOLOGY OF BATAK GRASSLAND FARMING}

George Sherman

Ahu pangaranto, sentabi, dao ma na maup
songon bunga ni ri.
--Ompu par-Medan

I am an emigrant, excuse the expression, drifting afar like the inflorescences of

"swordgrass."

--A city Batak, to his village kin

\section{Introduction}

In my field work in a traditional Toba Batak village cluster I discovered agricultural practices that the vast body of previous literature on the subject had assumed to be impossible. Specifically I found that the inhabitants of seven hamlets there, while farming wet-rice and bush fallow, were simultaneously working land covered by nearly pure stands of the much-decried Imperata cylindrica (L.)

* Funds for field research in Huta Ginjang/Sagala from July 1976 to June 1978 and a year's write-up support were provided by HEW and the Cornell Southeast Asia Program and supplemented by my parents and my wife. My wife's aid as mapmaker, statistician, cataloguer, participant observer, and nurse has been invaluable, and her encouragement has served as a beacon. An earlier draft of parts of this paper submitted in fulfillment of provisions of a field-assistant supportgrant from LEKNAS-LIPI (The National Institute of Economic and Social Research of the Indonesian Institute of Sciences) was published as "Tinjauan Pencelaan tentang percobaan penghijauan disekitar Pusuk Buhit, Tapanuli Utara," in Sinar Indonesia Baru, Medan, February 7-13, 1978.

In addition to the villagers, whose good-will I trust I have not betrayed, I am indebted to Ir. J. T. Wassink, Dr. J. P. Andriesse, and others of the Department of Agricultural Research, Royal Tropical Institute, Amsterdam, to Drs. P. Wijn, Mevrouw J. M. ter Poorten, and Mevrouw A. G. Kramer of the libraries of that Institute, to Dr. J. F. Veldkamp and others at the Rijksherbarium, Leiden, to Mevrouw E. Ensering of the University of Amsterdam Library, to Dr. P. Voerhoeve, to Meneer D. v. d. Meulen, to Professors M. L. Barnett, T. W. Scott, A. van Wambeke, R. E. McDowell, and H. L. Everett of the N. Y. S. College of Agriculture and Life Sciences at Cornell, and to the Staff of the Cornell Libraries, all of whom gave generously of their time in answering questions and providing references; and to Janneka Frankena for housing us in Amsterdam. Professors James Siegel, B. R. Anderson, B. Lambert and D. J. Greenwood read drafts of this paper and provided many helpful suggestions. The shortcomings which remain are not the fault of any of the above, but my own. 
Beauv., which Geertz and others have claimed has "turned . . . much of Southeast Asia into a green desert." $I$ How and why the impossible is, in fact, possible is the subject of this article.

There are two main subdivisions into which the agricultures practiced in Southeast Asia are usually grouped: on the one hand, swidden (shifting, slash-andburn) cultivation of dry fields; and on the other, sawah (wet-rice on irrigated terraces). Geertz's Agricultural Involution gives one of the best general descriptions of the pure forms of these types and of their concomitant ecosystems. He points out that wet-rice is found in Indonesia mainly on the "inner" islands of Java and Bali, and swidden agriculture mainly on the "outer" islands, such as Borneo, Sumatra, and Sulawesi. Perhaps more than was necessary, Geertz used the swidden-sawah (dry field-wet field) dichotomy to illustrate his thesis that under Dutch colonial rule the East Indies essentially developed two modes of agriculture, the inner, involuted, and the outer, noninvoluted. While there is an elegance of simplicity coupled with wide applicability in this dichotomy, and Geertz uses it as a metaphor for the kinds of agricultural strategies found among the majority of the archipelago's peoples, it is difficult to apply to three major ethnic groups of the northern half of Sumatra, the Minangkabau, the Achehnese, and the Batak, who all farm wet-rice. In addition, so to dichotomize strategies for farming ignores dry-field grassland farming which, as will be shown below, is widely practiced by Bataks. Both their wet-rice, and their methods of grassland farming appear to be ancient.

In his classic Pioneer Settlement in the Asiatic Tropics, on the first page of the chapter, "The Shifting Cultivator," Pelzer writes that "Practically without exception [the field of the shifting cultivator] is a clearing in either primeval or second-growth forest. The use of grassland is so unusual that we shall limit the following discussion to shifting cultivation on forest land." ${ }^{2}$ It is usually observed of slash-and-burn agriculture that too-frequently repeated cultivation of the same plot without a sufficiently long fallow period endangers the continuation of the cycle. As Hanks puts it:

When the land is overtaxed because the period of fallow has been too short to regenerate needed fertility, nature responds with soil erosion and nearly ineradicable weeds. This latter signal of impending trouble is cogon grass (Imperata cylindrica) that rises six or eight feet over a tangled root mass resistant to hoe, mattock and fire. . . . Here lies the terminal point for shifting cultivation, for though settlements may continue, economies must change to other techniques of cultivation or some other way of making a living, such as herding cattle. ${ }^{3}$

1. C. Geertz, Agricultural Involution: The Processes of Ecological Change in Indonesia (Berkeley and Los Angeles: University of California Press, 1970 [1963]), p. 10.

R. Pendleton, "Some Interrelations between Agriculture and Forestry Particularly in Thailand," Thailand Research Society Journal (Natural History Supplement), 12, 1 (1939-40), pp. 33-52, epitomizes the negative school of thought which flourished in colonial times, blaming the grass for everything from climatological features (which might be thought to depend on forces much greater than ground-cover--i.e., seasons/the distance of the earth from the sun), to the fall of the Angkorian and Mayan empires.

2. K. J. Pelzer, Pioneer Settlement in the Asiatic Tropics (New York: American Geographical Society, 1948 [1945]), p. 16 (emphasis added).

3. L. M. Hanks, Rice and Man: Agricultural Ecology in Southeast Asia (Chicago: 
But, note, even Hanks' description makes it sound as though the farming of Imperata is possible. It is resistant to the mattock and to fire but it is not immune, at least not to Batak methods. In fact, Hanks' description suits the Batak case. They do farm by other than typical slash-and-burn methods (particularly in that they turn the sod and break it up), and they do keep cattle as well.

\section{The Case Study}

Like perhaps a dozen other hamlet clusters in the Tapanuli regions of North Sumatra, the village is called Huta Ginjang, "top village." It perches on the north slope of Pusuk Buhit, "Mount Navel," which the Toba Batak claim to have been the birthplace of Si Raja Batak, the first man. This dormant volcano connects Samosir "island" (actually a vast peninsula) to the body of Sumatra. ${ }^{4}$ From its vantage, the village overlooks both the north end of Samosir and, to the west, the raised, stream-fed bowl of Sagala valley (invisible from the lake or from Samosir), a valley with one bottleneck egress, lying between the mountain and the crater-wall

Aldine-Atherton, 1972), p. 31. It should be recalled that B. J. Hagreis ("Ladangbouw," Landbouw, 6 [1930-31], pp. 43-76) was the first to depart from the accepted wisdom and argue that, with sufficient fallow, shifting cultivation was economically and ecologically viable. His work has been ignored, but the work of other scholars has made some progress in dispelling the universal condemnation which European administrators first heaped on "slash-and-burn" cultivation. See, among others: P. Gourou, L'utilisation du sol en Indochine Française (Paris: Paul Hartmann, 1940), pp. 347-48; G. N. Danhof, "Bijdrage tot oplossingkennis van het alang-alang vraagstuk in de Lampongsche districten," Tectona, 33 (1940), pp. 197-225; Pelzer, Pioneer Settlement; H. C. Conklin, "An Ethnoecological Approach to Shifting Agriculture," Transactions of the New York Academy of Sciences, 2, 17 (1954), pp. 133-42, and Hanunóo Agriculture: A Report on an Integral System of Shifting Cultivation in the Philippines (Rome: Food and Agriculture Organization of the United Nations, 1957). The most recent positive evaluation of shifting cultivation practices appears in P. Sanchez, Properties and Management of Soils in the Tropics (New York: Wiley-Interscience, 1977), pp. 368-70, 379, 389.

4. It should be noted that very few maps of Sumatra show the geography of this region correctly. Samosir is usually shown as an island, but only a 10-meter wide, 200-meter long canal that the Dutch had dug in 1916 makes it one. Most maps show only water in the place where Pusuk Buhit stands.

It is actually geologically correct to say that the peninsula, Samosir, is an island, while Mount Pusuk Buhit is a volcanic cone. According to $H$. Th. Verstappen, Samosir peninsula emerged after the Toba Crater Eruption (see his $A$ Geomorphological Reconnaissance of Sumatra and Adjacent Islands (Indonesia) [Groningen: Wolters-Noordhoff, 1973], pp. $124 \mathrm{ff}$.).

The inhabitants, however, make no distinction in their own topology between what is properly Samosir peninsula and what is properly Sumatran "mainland." Ancient areas of settlement around Pusuk Buhit and along the west coast of Lake Toba are, in fact, actually included in the designation "Samosir." Among them are the areas of Sagala, Limbong, Harian, Sihotang, Tamba, and Muara. People who live in these western lake-coast areas refer to making a trip to the peninsula, Samosir, as "going to Toba." Bataks from outside the area who are passing along the Tarutung-Sidikalang road which skirts the edge of the lake crater, just above Harian, refer to the entire area, including Pusuk Buhit, as "Samosir." Indigenous topology simply reflects both ecosystemic and cultural aspects of the fact that Samosir is the earliest Toba area of settlement. 
of the lake which encircles both. Hundreds of tourists a year pass within five kilometers of the village on "round-the-island" diesel-steamer tours and do not see it, because its existence is only signaled by what appears to be a tiny clump of trees in the vast, seemingly barren and uninhabitable expanse of brush and savannah which cloaks the mountain. A keen eye may note the occasional puff of smoke from some distant shoulder (the sign of a raging fire), the darker brown of cultivated areas of level terraces, or the deeper green which sets off ripening rice in scattered, minimally terraced patches high on the mountain. But even the ubiquitous stone terrace-work of the mountain's middle and lower reaches is normally hidden from sight by brush and Imperata-grass cover, at least until one reaches the environs of Pangururan, at the land-bridge that connects the island to the east side of the mountain.

Sianjurmula-mula, the purported site of the first Batak hamlet, the home of Si Raja Batak, is at the southern end of Sagala valley, at the foot of the spur connecting the mountain to the high plateau which extends west from the lip of the crater. It was on the way there that we passed Huta Ginjang.

First impressions, based on topography, that the villagers of Huta Ginjang subsisted entirely by dry-field agriculture, proved to be premature. About half of them owned and worked or rented wet-rice terraces down in Sagala valley, and (for the most part the same half) had floodable fields in the village as well. Beginning in the 1930s and resuming in the 1950s, more and more of them opted for cash-cropping shallots and garlic in the village fields which were irrigable, though they continued to grow at least half of their rice, both in valley wet fields and mountain dry fields.

Although a great deal of outmigration has occurred from the Samosir region and other Toba areas since the end of World War II, the number of households in Huta Ginjang-Sagala has doubled. While this was probably made possible by the advent of cash-cropping on a large scale, and by the availability of alternative (dry-) rice fields on the northeast side of the mountain--which was formerly farmed by canoe "commuters" from the peninsula of Samosir who have either emigrated or spend the local dry season farming wet-rice on claims in East Sumatra--it would not have been possible without the existence of traditional methods of eradicating Imperata cylindrica (. , alang-alang; Batak, ri), which tends to dominate long fallows.

In 1977 , out of 114 subsistence-and-consumption households in the village, 25 opened entirely "new" fields, many of which had been left fallow for so long that no one remembered who had last worked them; 24 other households widened grassland fields which they had first opened in 1976; and 43 other households opened mixed grass-bush fallow fields which they had inherited. The method of working grassland is certainly difficult. In order to succeed it requires foresight, hard work and patience.

Most of the work of opening grassland fallow is started between April and early July (as the dry-season winds begin to pick up). The various times chosen depend on considerations of location and scheduling the harvest of rice and other crops. Work is scheduled with a view to planting rice by the beginning of the following rainy season which begins between October and December. At present, Imperata is often cut and taken off to be used as mulch, or made into thatch (though most houses now have corrugated zinc roofs). Otherwise, the field may or may not be burned over if the vegetation is dry enough. The ground is then broken up and turned, a task usually done by four or five men who drive their mattocks into the sod, section by section, in unison, and then heave and pull a section of sod over. On average they can turn a three-foot long, one-foot 
wide, eight-inch deep pallet of sod at a time. They move in rows back and forth across the field. It requires some thirty-five man-days to open an acre (.4 hectare), and the result actually resembles a field which has been plowed by means of a mole-board plow. ${ }^{5}$

The field is then left to bake in the hot sun so that the rhizomes of the Imperata lose their resilience. The size of the pallets of sod helps reduce the number of new shoots sent up, since these come mainly from the edges which are exposed to light. After a month or six weeks, the field is reworked, and the pallets of sod are chopped up into large chunks. (This and further steps of the process can be carried out by single individuals, including women. Couples often work together on such tasks.)

The smaller chunks of sod are again left to dry further for as long as a month, after which a third working breaks them down completely, knocking rhizomes and roots of bushes loose from the soil. The plant residues are then raked out of the soil and are either burned or left in rows perpendicular to the slope to prevent erosion.

An average household divides its energies in the cultivation of five separate dry fields in the course of a year, in addition to small wet-rice holdings in Sagala valley. Thus there is plenty of other work to do between the steps of the job of opening grassland. Some fields are used almost constantly and receive manure spreadings two or more times a year. Imperata is never allowed to invade them. Others are left fallow after one or two harvests in succession, and are reworked after from one to three years.

A variety of means are used to prevent the loss of topsoil. Most "fields" are terraced, the surfaces being slightly inclined so that rainwater flows into watercourses along the base of the next-higher terrace, rather than over the wall of the terrace on which it falls. Crops such as shallots, garlic, and coffee are mulched to whatever extent possible with rice stalks as well as with Imperata cut specifically for the purpose. Watercourses are also dug on steep slopes above fields. In addition to these characteristic features of cultivation, the features of livestock husbandry are also important and will be briefly described.

Much of the livestock (cows and water buffalo) is jointly owned by the heads of several households, who rotate the stock from one stall to another, taking turns in pasturing the animals and in recovering their manure. (For the most part, young boys and girls are given the task of herding the animals after school.) In the past, the ownership of livestock was a sign of being rich and of being capable of holding large feasts, considerations which are still important. Water buffalo are also used for drawing the plow in wet-rice fields, as well as for harrowing. But the most oft-repeated reason given for the high value placed on owning some share of bovine stock is the practice of manuring, a technique which, it is claimed, was introduced by the Dutch. ${ }^{6}$

5. The average newly opened field was 0.7 acre $(7 / 25$ hectare), although several might be opened by the same household in a given year, on different parts of the mountain.

6. There is some independent evidence to confirm this claim. Informants' statements that bulb crops were introduced some forty years ago, i.e., in the mid-'30s, are borne out by the report of L. van Bemmelen, "Vervolgmemorie van overgave van de onderafdeeling Samosir" (1931) (typescript in the SWO Library of the Royal Tropical Institute [henceforth KIT], Amsterdam), pp. 15-16. Here he wrote that the appointed negri heads were shown the methods used, including manuring, 
The keeping of livestock necessitates providing for their fodder. While Imperata is often denigrated in this regard, as being coarse and unpalatable, such an indictment is only applicable to the mature stage of its growth. Furthermore, even authors who do so denigrate it have come to admit the necessity of burning tropical pastures. Thus, while Sanchez claims it is "practically worthless for grazing," he points out that the practice of burning

is easily condemned by people unfamiliar with the system, citing ecological damage. . . . An examination of the available data, however, indicates that periodic burning is essential for maintaining the stand and productivity of many natural grasslands and that the frequency and timing of burning operations are important. . .

The primary reason for burning is to destroy the dry, unpalatable grass stands and to promote the regrowth of younger, more palatable grass shoots. . . . ${ }^{7}$

Although it is easy to be shocked at the sight of blackened, seemingly bare and easily erodable swathes in the landscape after a burn, it needs to be kept in mind that the rhizomes resprout with increased vigor after a few days. They are unharmed by the fire. What, on first sight, appears to be a vast black wound in the landscape will, within a few weeks, turn light green. Sanchez writes of the burning of cut forest: "Contrary to popular belief, burning in the process of shifting cultivation does not destroy soil organic matter. Soil temperatures during burning are not high enough . . . except in reburn pile situations"; ${ }^{8}$ and of the

when they attended periodic rapat (meetings) at the behest of the Controleur who resided at Pangururan; and he added, "during the past year many onions were planted. . . . This crop will thrive here. The Agricultural Information Service tested [ways of] increasing the yield by manuring. . . . I think it advisable - . that the Native Heads set an example, which the people will follow by themselves." Dutch demonstration projects involved a variety of cash crops, shallots, garlic, coffee, and cabbage.

7. Sanchez, Properties and Management, p. 538. Although Imperata is not dealt with in the standard textbook on the subject (R. E. McDowell, Improvement of Livestock Production in Warm Climates [San Francisco: Freeman, 1972]), research by E. P. Sinaga at the Agricultural Institute of Bogor (based on B. Soewardi, D. Sastradipradja, A. H. Nasoetion and J. H. Hutasoit, Studies on Alang-alang (Imperata cylindrica ( $L$. ) Beauv.) for Cattle Feeding [Bogor: Biotrop (SEAMEO), Bulletin No. 8, 1974]) indicates that during the first few months of growth, new sprouts of Imperata compare favorably with other grasses in protein and dry-matter content. From the age of three weeks to nine weeks, dry matter rises from 21.3 percent to 42.8 percent, while "rough protein" falls from 12.1 percent to 6.2 percent (E. P. Sinaga, "Pemanfaatan Alang-Alang Sebagai Sumber Makanan Ternak," Sinar Indonesia Baru [Medan], January 31, 1978, p. 7). According to McDowell ("Are U.S. Animal Scientists Prepared to Help Small Farmers in Developing Countries?" [Ithaca: Department of Animal Science of the NYS College of Agriculture and Life Sciences, 1977], pp. 11-12), dry-matter content needs to be between 20 and 30 percent for optimum milk production. Note that the Batak only rarely produce milk. Calves are restricted only by their mothers.

Sanchez groups "attempts to improve the productivity of native tropical grasslands" into three categories: "improved burning and grazing practices, fertilization, and oversowing legumes with fertilization" (Properties and Management, $\mathrm{p}$. 539). Note that, of these, the last two are impractical to all intents and purposes, being capital-intensive.

8. Sanchez, Properties and Management, p. 368. 
burning of grassland: "Burning is a rapid process: a curtain of fire travels quickly along the grass. It is likely, therefore, that its effect on soil properties are less marked than those of forest burning. . . . Native grasses . . . are well adapted to this process." 9

The villagers know that cows prefer young shoots of Imperata; and, although they were unaware that the protein content of such shoots is much higher than in the mature grass, they distinguish the two. Mature Imperata is called ri or lalang (Ind., alang-alang), while the grass in the process of resprouting is referred to as "tulmok," which Warneck translates as "short and thick." 10 "Yes," said one man, "we always tell the children, 'Take the cows to that tulmok over there."

The point of this is that Samosir has traditionally been a net exporter of livestock to the surrounding regions, Dairi, Simalungun, Toba, and the East Coast. ${ }^{11}$ The meat is probably not up to American standards, nor should it be expected to conform to those standards (which some would argue to be unhealthy); on the other hand, the livestock does not require grain feeding, and the pasture does not require phenoxy herbicides. There is, thus, complementarity between raising livestock and farming grassland.

\section{Some Pan-Batak Evidence}

It was a relief for this researcher to find he was not the first to have noticed the singularity of Batak dry-field farming. In one of the earliest European accounts of a journey through the Angkola region of southern Tapanuli, F. Junghuhn, a German botanist, wrote in a report to the Governor-General on Java that he found half of the agriculture to be on wet-rice fields and the other half on dry fields. And he continued:

Mainly the not so steep and humus-rich slopes are covered with ladang [dry-fields] . . . whether old or new . . . surrounded by woods. . . It is used just once a year for rice culture and then in the second half of the year is usually planted with corn. Then it is allowed to lie fallow for a year or two and becomes covered by new weeds, usually alang-alang or klaga grass which can grow 10 to 12 feet high. . . Then in the driest part of the year they set fire to this wild grass. . . At night such fires moving up the mountain slopes and wandering from place to place just like streams of lava make a beautiful sight. During the daytime the smoke covers the landscape for miles ... impeding the view like the high smoke from the burning of the moors in Europe. . . .

The ash of the wild which has thus burned more or less assures the best cover for the newly opened fields. . . . Only the black humus-rich layer of newly cut woods is more fertile. The straining labor that the tree-

9. Ibid., p. 568 .

10. J. Warneck, Toba-Batak-Deutsches Wörterbuch, rev. ed., R. Roolvink (The Hague: Nijhoff, 1977), p. 273.

11. See $W$. Middendorp, "Memorie van Overgave v. d. onderafdeeling SAMOSIR," 1913 (typescript copy belonging to D. v. d. Meulen), pp. 26-29, on the export of horses and buffalo, where he records an export of 600 horses. W. G. Haibach, "Vervolgmemorie van de onderafdeeling Samosir," 1927 (typescript in SWO library of the KIT) gives livestock population as 9,218 buffalo, 4,870 horses, 5, 244 cows, 14,282 pigs, 7,143 goats, and 3,530 sheep (p. 22), and reports an export of buffalo worth $f$ (guilders) 80,840 , horses worth $f 11,820$, cows worth $f 15,600$, (about 800 buffalo, 3-400 horses, and 3-400 cows), and smaller amounts for other animals. 
cutting requires is the cause that the Batak only rarely [i.e., when population expands or at the forming of new families] feel impelled to go and make completely new fields [in forest]. . . ${ }^{12}$

In other words, Junghuhn reported that the Bataks of the Angkola region preferred to work Imperata-covered dry fields than to cut forest. Later in the same passage he notes that even on newly cleared forest or secondary forest ground, they turned in the ashes by rooting up the soil with a wooden pick-axe (hakke)-a practice not commonly found in slash-and-burn cultivation.

Junghuhn's observations went unremarked until Bartlett, himself a botanist, in Volume I of his massive annotated bibliography, noted the paradox: "Junghuhn said that the ashes of burned-over 'wilderness' provided enough fertilization for renewed cultivation, but he did not tell clearly how a crop could be obtained after only a short fallow during which woody plants had not yet supplanted grass." 13 In fact, Junghuhn does give an indication as to how this was done, and Bartlett goes on to consider it in the next sentence:

He did speak of cultivating the land with wooden hoes, but that was in connection with newly cleared land. . . This might have included uprooting the clumps of galaga grass, for in Karoland, farther north, the [Karo] Batak actually turned the refractory lalang sod with digging sticks to make gardens in choice and accessible spots, as von B renner and later visitors observed, and the more southern Batak may have done the same. . . ${ }^{14}$

Nevertheless, he concludes that:

reutilization of grassland could not have been, as Junghuhn thought it was, less difficult than clearing more primary forest. One suspects that in troubled times the people did not dare to venture too far from their permanent villages and so resorted to more laborious forms of cultivation than ordinary ladang cultivation. ${ }^{15}$

Yet in a separate article, Bartlett again tells us that his own observations of the Karo Batak (made at a time when Pax Nederlandica had overtaken the Karolands), confirmed those of von Brenner, who "described a row of Karo women with digging sticks working side by side to turn a furrow in grassland . . . an almost unique instance of digging stick cultivation among the Malayan peoples that was not at the expense of forest." 16

12. F. Junghuhn, Die Battaländer auf Sumatra, vol. 2 (Berlin: Reiner, 1847), pp. 190-91. (Text in brackets paraphrased.)

13. H. H. Bartlett, Fire in Relation to Primitive Agriculture and Grazing in the Tropics: Annotated Bibliography, 3 vols. (Ann Arbor: University of Michigan Botanical Gardens, 1955-61), 1, p. 332. Junghuhn's description was ignored by, among others, C. J. Westenberg, "Nota over de onafhandelijke Bataklanden," Tijdschrift voor Indische Taal-, Land- en Volkenkunde (henceforth TBG), 34 (1891), pp. 105-16, and A. L. van Hasselt, "Nota betreffende de rijstcultuur in de Residentie Tapanoeli," $T B C, 36$ (1893), pp. 502-30, both of whom E. C. J. Mohr drew on for his description of Batak agriculture, in The Soils of Equatorial Regions with Special Reference to the Netherlands East-Indies, trans. R. L. Pendleton (Ann Arbor: Edvards, 1944).

14. Bartlett, Fire in Relation, 1, p. 332.

15. Ibid.

16. H. H. Bartlett, "Fire, Primitive Agriculture and Grazing in the Tropics," in 


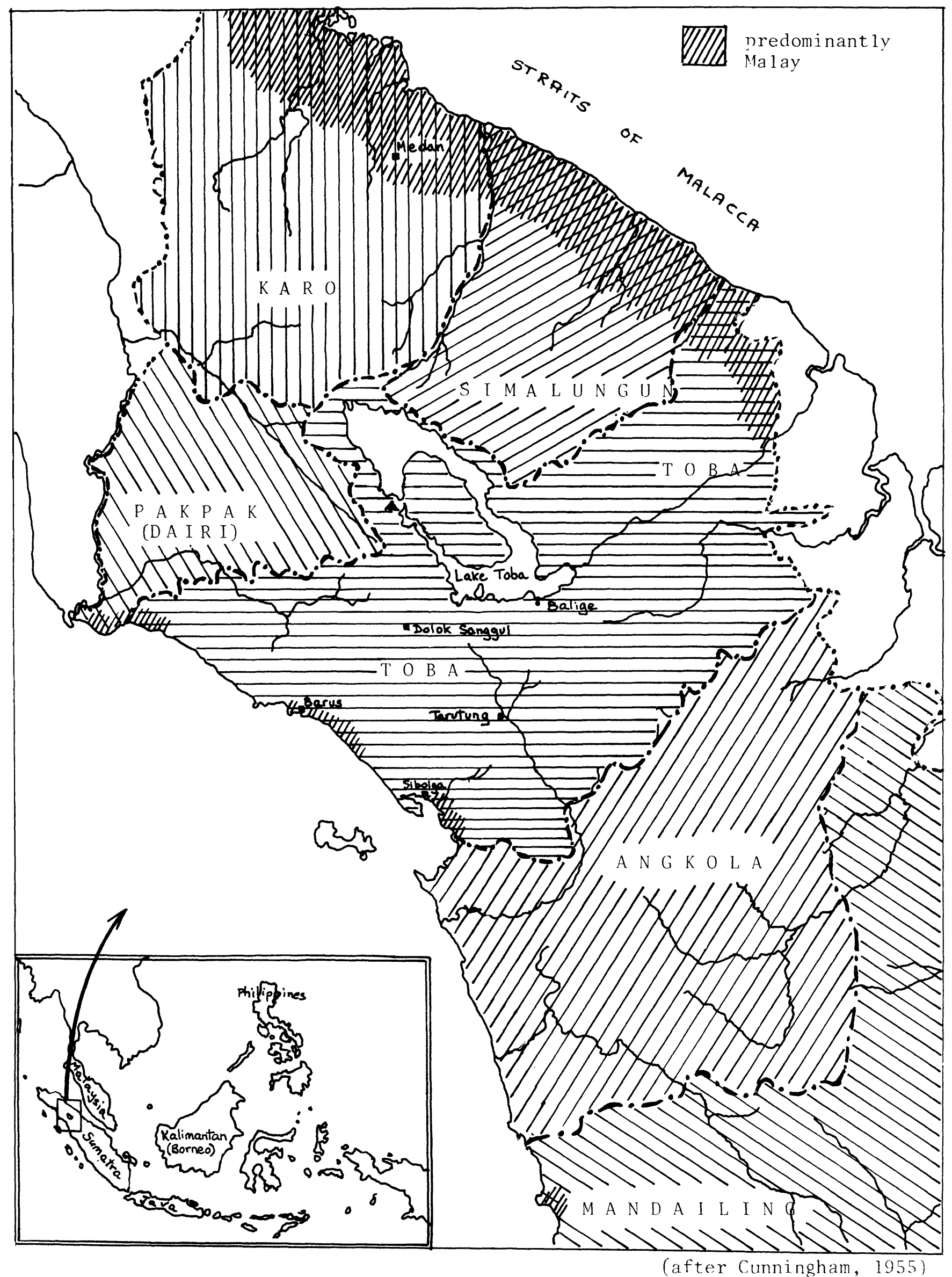

IAP II.

TRADITIONAL BATAK TRIBAL AREAS 
But this is not all. Bartlett was further confronted by the evidence of Hagreis and Vonk. Writing in the agricultural journal of the Indies, Landbouw, in 1927, they provided a complete description of Toba Batak dry-field farming which generally corresponds to the system which this writer observed, though with longer periods of cultivation, on nearby Pusuk Buhit fifty years later. After describing wet-rice cultivation, they wrote:

In addition to . . . sawah [wet-rice] farming an intensive ladang agriculture is evident on the highland [Toba] plateau, giving high yields. [It is] labor intensive. The ground is, however, not intensively used: a ladang lasts only a year and cannot be reused earlier than after six years. The tilling takes place in the dry season. The plot ... is first roughly hoed up. Then it is again hoed, the sods are gathered in piles and burned when dry. At the start of the rainy season the ashes are scattered about the ground which is again hoed up. . . .

. . This dry-field agriculture is thus extremely different from the more generally known clearing of forest for ladang. I5

Rather than attempt to explicate the evidence of Batak grassland farming on agronomic or other grounds, Bartlett tried to classify these methods as "sod-burning which is carried out in some parts of India and tropical Africa." 18 However, in a later article, which Bartlett also discusses, Hagreis argued that ladang agriculture was not entirely the "robber agriculture" that colonial authorities had deemed it to be, and he clarified the first description, noting that it is "undecayed wastes," rather than sods, which the Bataks burn. ${ }^{19}$ In fact, the burning takes place only after successive workings have freed all but the densest tussocks of remaining soil. ${ }^{20}$

We may infer the existence of similar methods among the Simalungun Bataks as well. Tideman wrote that the Simalungun devastation of the forest had "reduced some cultivators to the necessity of using [Imperata] plains. . . ."21 This may have been a subjective judgment, but it points up the fact that they had methods of farming it--eradicating it for purposes of growing crops. According to Dr. P. Voorhoeve, in fact, in Simalungun there were two types of farmers: urang $r i$ and urang harangan (harangan, the pan-Batak word for forest). He adds that the terms were applied to the districts they inhabited as well. Furthermore, he observed, the Karo Batak "aron" system (of cooperative work groups, composed

Man's Role in Changing the Face of the Earth, ed. W. L. Thomas, Jr. (Chicago: University of Chicago Press, 1956), pp. 704-5, citing J. F. von Brenner, Besuch bei den Kannibalen Sumatras (Wurzburg: Woeri, 1894).

17. B. J. Hagreis and H. Vonk, "Beknopte beschrijving van den inheemschen landbouw in Tapanuli," Landbouw, 3 (1927-28), pp. 688-89.

18. Bartlett, Fire in Relation, 2, p. 618.

19. Hagreis, "Ladangbouw," p. 50.

20. Sod or turf burning elsewhere, as cited by Bartlett (Fire in Relation, 2, p. 755 from W. W. Hunter's Statistical Account of Assam, vol. 2 [London: Trubner, $1879], p$. 223), also appears to have involved too long an interval between the ground turning and the burning (a period of five months) to have been of sod.

21. J. Tideman, Simeloengoen: het land der Timoer Bataks in zijn vroegere Isolatie en zijn Ontwikkeling tot een deel van het Cultuurgebied van de Oostkust van Sumatra (Leiden: Becherer, 1922), cited in Bartlett, Fire in Relation, 1, p. 514. 
of men and women) was specifically based on an agriculture which works Imperata. ${ }^{22}$

Prior to the introduction of the heavy iron mattocks (cangkul) which Hagreis observed in use by Toba grassland farmers, they, and probably the Simalungun as well, undoubtedly used digging poles similar to the ones used by the Karo. The Karo, too, now use mattocks. But aside from the adoption of a better tool, the method remains the same. In spite of differences in the organization of work groups, it can be said generally that four of the major Batak subtribes, the Toba, Karo, Angkola, and Simalungun Bataks, practiced similar methods of farming Imperata grassland in areas where the need to do so arose. ${ }^{23}$ All were, of course, capable of bush-fallow cultivation, and of cutting primary forest either for agricultural or building purposes. Furthermore, the Toba and the Angkola in particular built extensive irrigation systems to supply water to terraces made of rock or packed earth, for wet-rice.

At present, the Toba Batak farm grassland, not only at the fringes of their region proper (as on Pusuk Buhit), but, judging by newspaper reports, in areas as diverse as the vicinities of Tarutung (in the early-Protestantized Silindung valley) the seat of the regional capital, and of Dolok Sanggul. Cases of protests lodged at the expropriation of such ancestral lands for government forestry programs were frequently reported while I was in the field. For example, from a village near Tarutung: ". . The reason given [for the protest] was that since the earliest times to the present these plains had been used by their ancestors for dry fields. They constitute a resource of additional subsistence to add to the yields of working their barren sawah." 24

22. Interview with Dr. P. Voorhoeve, August 1978. There are photographs in the Collection of the Royal Tropical Institute, Amsterdam, of as many as twenty Karo women and men, in a row, with "digging sticks" (actually pointed poles, almost twice as long as the people are tall), turning pallets of Imperata-sod in unison. According to R. Oudemans ("Simalungun Agriculture: Some Geographical Aspects of Dualism in Sumatran Development" [Ph.D. Thesis, University of Maryland, 1973], p. 57), it is "very hard, if not impossible to eradicate [Imperata] with their traditional tools," an insinuation that is contradicted by the observations of both Tideman and Voorhoeve.

23. This is not to say that this was the case in all Toba or other subtribe areas. The practice of grassland farming provides an extreme contrast, for example, to the one-crop-a-year sawah system of Lintong ni Huta, at the southern end of the lake, near Balige, which is taken as a negative example in D. Penny's "Transition from Subsistence to Commercial Family Farming in North Sumatra" (Ph.D. thesis, Cornell University, 1964). The essentials of Penny's description of the latter economy were recently corroborated by $\mathbf{R}$. Lando (personal communication, May 1976).

24. The above is from the article, "53 orang penduduk mohon perhatian Dinas Kehutanan Tapanuli Utara atas Pengukuran Dan Pemancangan Tanah Daratan 'Parbalean Parrongitan,"' Sinar Indonesia Baru, November 7, 1977. See also articles in the following issues of Sinar Indonesia Baru: September 20, 1977; October 21, 1877; November 18, 1977; December 1, 1977; February 22, 1978; February 27, 1978.

Traditional pasture, "native grasslands," are considered to be "tanah kosong," "empty" or "wasteland," by the powers that be, since this is what was taught in their Western training. It is even claimed that forest cover will make it rain during the dry season monsoon, although why the immense evaporating surfaces of 
The Paradox in the Ecosystem Paradigm

Batak farming of grassland poses problems for agronomic accounts of tropical ecosystems, since most such accounts attribute to grassland a kind of self-destructive tendency to ever-greater leaching and erosion. It is thus necessary to examine the ecosystemic model, based on which such conceptions have taken hold.

Of the fallow period in a shifting cultivation cycle Pelzer writes that "when tall forest growth again occurs, the land will have had time to recover its original fertility." 25 And we have seen Hanks make a similar statement. According to this ecosystemic model, grassland spreads and takes over from forest in the tropics when the fallow period is not long enough and, because of population pressure, the land is reworked without sufficient intervals of fallow. It is given a higher likelihood of occurring when the area has been completely deforested, making it difficult for deciduous trees to reseed themselves. Men set fires to provide fodder when the grass becomes too tough for their cattle, or as hunting aids; or fires spread from forest-cut plots and, while this kills tree seedlings which may be growing, Imperata grass is only momentarily checked and soon resprouts with even greater vigor.

The model is one of ecosystemic breakdown. Not only does grassland spread at the expense of forest but, it is also claimed, the spread of grassland permanently reduces the potential of the land. Thus the model has led to the widespread assumption that the grassland is unfarmable or cannot possibly be made to produce "economically." The problem with this model of breakdown may well lie in the very terms in which it is framed, of whether or not the land will have had time "to recover its original fertility" before being reworked. To get to the crux of what is wrong with this framework Pelzer himself can be cited. At the Ninth Pacific Science Congress he remarked:

Ever since the first European explorers beheld the luxuriant plant growth of the tropical rain forest, observers coming from the mid-latitudes have drawn the faulty conclusion that the rain forest is an indicator of high soil fertility. This myth of the extraordinary fertility of the tropics as the cause of the apparently endless stretches of magnificent forest growth . . . refuses to die. Although it is true that some luxuriant tropical rain forests grow on truly fertile soils, actually, all too often tropical forests stand on extremely impoverished soils.

Modern soil science has provided us with an adequate explanation for this baffling phenomenon of luxuriant plant growth on poor, badly leached soils. . . . Most of [the] plant-nourishing minerals which made growth possible are either fixed in the vegetation or have been washed out and carried away. . . . The plant nutrients contained in the plant waste . . are almost entirely taken up again by the roots of the trees and other vegetation. . . . This explains the absence of a deep layer of humus in the tropical rain forest. 26

Geertz reiterates the gist of Pelzer's description in the following: "The role of

the Lake and the surrounding seas do not provide enough atmospheric moisture at that time is unclear.

25. Pelzer, Pioneer Settlement, p. 18. See also n. 3 above.

26. K. J. Pelzer, "Land Utilization in the Humid Tropics: Agriculture," Proceedings of the Ninth Pacific Science Congress, 1957, vol. 20 (Bangkok: The Secretariat of the Ninth Pacific Science Congress, 1958), p. 125. 
humus in creating a topsoil storehouse of nutrient materials in colloidal form . . . is [under tropical forest conditions] minimized; organic materials rarely extend in significant quantity more than a few inches beneath the forest floor." 27

How, we may then be prompted to ask, does it happen that shifting cultivators are reported to derive reasonably good yields in the first season after carrying out their slash-and-burn operations? For both Pelzer and Geertz would seem to imply that, unless the cultivators happened to hit upon a fertile area, poor yields would be the rule rather than the exception. In fact, Geertz has provided the answer in analyzing the ecosystem of swidden:

The burning of the slashed plot is at base a means both of accelerating the process of decay and of directing that process in such a fashion that the nutrients it releases are channeled as fully as possible into certain selected food-producing plants. A significant proportion of the mineral energy upon which swidden cultivates [i.e., cultivated plants], and especially the grains, draw for their growth comes from the ash remains of the fired forest, rather than from the soil as such, so that the completeness with which a plot is burnt is a crucial factor in determining its yield. . . ${ }^{28}$

Evidence of the degree to which shifting cultivators are aware of the importance of how well burned the field is, of its effect on yields, and of the uncertainties surrounding a good burn--too soon, and it will not have had a chance to dry sufficiently; too late, and it will be irreparably soaked by the onset of the rainy season--is available in eloquent descriptions for the Hanunoo, ${ }^{29}$ the Iban, ${ }^{30}$ the Sumbawans, ${ }^{31}$ and others.

As Geertz writes: "The burned forest provides most of the resources for the cultivates. . . . ${ }^{32}$ But this realization has not led him, or other commentators who realize this, to attack the model whereby it appears that, after long fallow, "the soil is again replenished with heavy debris." 33 It is ash which replenishes the soil or, to put it another way, the fertility of the soil does not increase until the forest is burned. Even where suitable rock containing potassium and phosphorus occurs, its slow breakdown would be taken up by tree growth, and the minerals would not be stored in the land. And, in fact, we do not find swidden cultivators themselves referring to soil fertility per se as a criterion of judgment. According to Conklin, "In distinguishing general and specific soil types, the Hanunóo use eight criteria: moisture content, sand content, rock content, general texture, firmness, structure in dry season, stickiness in wet season, and color." ${ }^{34}$ Of the more intensive-farming Kofyar, Netting writes that they "classify soils by

27. Geertz, Agricultural Involution, p. 21.

28. Ibid., p. 22 .

29. Conklin, Hanunóo Agriculture, pp. 64-72.

30. D. Freeman, Report on the Iban (London: The Athlone Press, 1970 [originally published in 1955 as Iban Agriculture by Her Majesty's Stationery Office]), pp. 177-83.

31. P. R. Goethals, "Rarak: The Annual Swidden Cycle," Indonesia, 20 (October 1975), pp. 122-26.

32. Geertz, Agricultural Involution, p. 24.

33. Hanks, Rice and Man, p. 30.

34. Conklin, Hanunóo Agriculture, pp. $36 \mathrm{f}$. 
color, texture and moisture content." ${ }^{35}$ And Hanks notes:

- . Condominas describes an old Mnong Gar of Vietnam returning to inspect a plot used 20 years previously. Vegetation had not grown sufficiently; they decided not to use it. A Meo showed me, on a trip through the hills, the fields that his village used 12 years earlier, but weeds rather than bamboo covered the hillside. . . The time was not yet ready for fresh cultivation. .... ${ }^{36}$

And yet, as we saw above, Hanks himself rephrases these observations to conform to our own, temperate-climate-based notions of soil fertility (". . . land is overtaxed . . . fallow too short to regenerate needed fertility. . . .") while in actuality, the field is left fallow to grow up in secondary forest in order to allow the biomass to build itself up again so that when it is burned its ashes will fertilize at least one good crop. No matter how long a time forest land remains fallow its fertility does not increase. This has recently been proven with a hitherto unparalleled degree of certainty by Dr. J. P. Andriesse, of the Soil Sciences Division of the Royal Tropical Institute, Amsterdam. Testing fields which had been from one to twenty years fallow, in a shifting cultivation cycle in Sarawak, North Borneo, he found no significant change in the levels of nitrogen, phosphorus, potassium, calcium, magnesium, or carbon in any. The duration of fallow made no difference in fertility levels of the soil (i.e., of the land). ${ }^{37}$

It is testimony to the appeal and logical consistency of the "breakdown" model of what was thought to be soil fertility in a cycle of forest regeneration that not even Geertz dwells on the fact that this model was quite conducive to the intensification of colonial agroeconomic policies. Yet it is clear that their antiswidden stance helped in the virtual enslavement of Java which Geertz has so well documented. For instance, he tells us that in 1870 the Agrarian Land Law codified "the convenient notion . . . that all uncultivated 'waste land' is inalienable state property . . . making it possible for private plantation concerns to lease such land on a regularized, long-term contractual basis from Batavia and to use such legal titles for the purposes of obtaining credit." 38 Yet this and other laws, such as the 1879 law against burning of grassland, ${ }^{39}$ fail to alert Geertz to the possibility of built-in political bias in the reports of Imperata's perniciousness.

35. R. M. Netting, Hill Farmers of Nigeria: The Cultural Ecology of the Kofyar of the Jos Plateau (Seattle: University of Washington Press, 1968), pp. $83 \mathrm{f}$. In many respects, as will be shown below, the grassland ecosystem, in which much Kofyar farming is done, differs greatly from the forest ecosystem under discussion here. So it is an interesting parallel that the Kofyar also judge fertility by the amount of vegetational regrowth. Of their "common wild grass (togos) used for thatching," which is clearly an Imperata species (see Plates I.A, III.1), Netting writes: "if the grass reaches six feet or more in one season the field is ready for another cropping cycle ..." (loc. cit.; also, ibid., p. 197).

36. Hanks, Rice and Man, p. 31.

37. J. P. Andriesse, "Nutrient Level Changes during a 20 Year Shifting Cultivation Cycle in Sarawak (Malaysia)," Paper presented to the ISSS conference "CLAMATROPS," Kuala Lumpur, Malaysia, August 15-20, 1977 (bound mimeo, Amsterdam: KIT, 1977).

38. Geertz, Agricultural Involution, p. 84.

39. G. van Herwerden, "Eenige beschouwingen over de bestrijding van de roofbouw der Inlandsche bevolking in Nederlands-Indie," Koloniaal Tiidschrift, 
It is ironic that the Dutch, who branded shifting cultivation "robber agriculture," practiced it on a wide scale themselves in the East Coast region of north Sumatra. For the first thirty years of the existence of the tobacco plantations there, yearly planting was done on land cleared of primary forest for the purpose. After that, in the $1890 \mathrm{~s}$, as O'Malley writes, "an interim fallow period of approximately eight years between use was discovered to be sufficient to allow the land to . . be able to support another tobacco crop. . . By the time this discovery was made Deli was 'one great grass plain'. . . " 40 The mostly Malay, Karo Batak, and later Simalungun Batak indigenes, living in plantation concessions which were granted by the Sultan of Deli and the Sultan of Langkat, were permitted to plant their (formerly swidden) crops on tobacco land for one year after the cigar-leaf harvest.

Pelzer ${ }^{41}$ claims that, in the opportunities given to the indigenous inhabitants of these "concessions," a symbiosis was established in which both parties benefited. As O'Malley points out, this contrasts with Geertz's position that the arrangement was "neutral." 42 Whichever characterization is more clearly correct, Geertz's reasoning that the swidden ecosystem was "not seriously altered even in an involutional manner by its encounter with the estate tobacco system [because] unlike the sawah system, it was incapable of such alteration; any serious attempt to intensify it would have led to grass-field erosion and would have harmed both systems. . . . 43 no longer seems valid. The dry-field ecosystem was not altered, because "involuted swidden"--not swidden at all, actually--was already part of the systems of cultivation, not only in Toba (Tapanuli), but also in the foothills south of Medan and east of Lake Toba, i.e., the Simalungun Batak region that became

Vereeninging van Ambtenaren bij het Binnenlandsch Bestuur in Nederlands-Indie, 51 (1916), pp. 9-16, 145-64.

It should come as no surprise that in all the time it was assumed that forestcovered soil regenerated its former fertility while grassland caused erosion and leaching, no tests were done on the possibility of increased fertility levels under grassland conditions. L. Judd (Dry Rice Agriculture in Northern Thailand, Southeast Asia Program Data Paper No. 52 [Ithaca: Cornell University, 1964], p. 13) proposed periodic soil testing of swidden sites as "a significant research problem for the future."

40. W. O'Malley, "Indonesia in the Great Depression: A Study of East Sumatra and Jogjakarta in the 1930's" (Ph.D. thesis, Cornell University, 1977), p. 147, n. 19, citing, among others, K. Pelzer, "Western Impact on East Sumatra and North Tapanuli: The Roles of the Planter and the Missionary," Journal of Southeast Asian History, 2 (1961), pp. 67-68.

41. K. J. Pelzer, "The Agrarian Conflict in East Sumatra," Pacific Affairs, 30 (1957), p. 155. Incidentally, the grass was even blamed for the fact that, when it was kept from resprouting, the plantations of the British in Malaya were exposed to erosion: "An indirectly harmful effect of the grass in Malaya, a country of heavy rainfall .. . has been the severe erosion resulting from the once prevalent policy of clean weeding large rubber estates from the time of their establishment" (A. P. Gray, "The Effect of Imperata Cylindrica on Economic Crops," in Imperata Cylindrica: Taxonomy, Distribution, Economic Significance and Control [Aberystwyth: Imperial Agricultural Bureaux, 1944], p. 24).

42. O'Malley, "Great Depression," p. 147, n. 21; Geertz, Agricultural Involution, p. 108.

43. Geertz, Agricultural Involution, p. 111. 
the site of many plantations. As will be shown below, Imperata grassland farming was, and remains, a viable alternative to the more common forms of slash-andburn.

\section{The Ecosystem of Imperata Grassland}

It is now necessary to consider the grassland ecosystem, because it often seems that the belief that tropical grassland grows on thin soil which it allows to deteriorate further, due to erosion, percolation, and leaching of rain water, is a correlate of the misconception of forest-covered soil conditions. While the correlate of a misconception is not necessarily wrong, there are crucial differences between the two ecosystems which imply that this one is.

Nye and Greenland claim that, in Southeast Asia, areas covered by Imperata "are useless for cultivation." 44 Their account, based mainly on African materials, is still useful for an understanding of the grassland ecosystem and Batak cultivation of grassland. I will use it to suggest a possible revision in the usual agronomic evaluations of grassland. They claim, to begin with, that "in the savannah . . . the grass and other herbs may be slow to form a complete cover over the ground." 45 This may be because they are left to form such a cover after harvest, during the driest part of the year, but, even then, there are many quick-growing weeds which form a dense cover. (See below, Appendix, pp. 147-48.)

Since grasses are eaten, cut, or burned with much greater frequency than secondary forest, they claim that "unlike the forest fallow the grasses do not continue to increase their store of nutrients year by year. . . . The burning also reduces the build-up of humus in the top soil by reducing the amount of litter supplied to the soil organisms. . . " 46 It should be noted that not all of the savannah is burned every year. More importantly, the rhizomes of the grasses do not live forever. Newly turned-up ground often reveals rhizomes in various stages of decomposition. As Sanchez notes: "Fresh organic matter additions in grasslands are primarily in the form of root decomposition." 47

But Nye and Greenland maintain that "the natural grass savannah is a poor means of restoring the fertility of the land. It stores only small amounts of nutrients and it maintains a chronic shortage of available nitrogen. . . . The increase of humus in the top inches of soil and the maximum level possible are considerably less than those under forest. . . "48 The comparative lack of humus in tropical forest has already been pointed out. As Sanchez puts it, tropical rainforests "produce about five times as much biomass and soil organic matter per year as comparable temperate forests. The rate of organic matter decomposition, however, is also about five times greater than in temperate forests. Thus the equi-

44. P. H. Nye and D. J. Greenland, The Soil under Shifting Cultivation (Harpenden: Commonwealth Agricultural Bureaux, 1960), p. 9. In spite of the vast amount of research in this field done since this work was published, it remains a key reference. Sanchez refers to it often (see, for example, Properties and Management, pp. 349, 365, 372, 379).

45. Nye and Greenland, Soil, p. 10.

46. Ibid., p. 11 .

47. Sanchez, Properties and Management, p. 170.

48. Nye and Greenland, Soil, p. 135. 
librium contents are similar." 49 Continuing, Nye and Greenland argue that "owing to the absence of a complete soil cover, and the reduced amount of litter, the soil surface is more compact and less permeable [under grass cover]." 50 This point is well taken, but the authors fail to draw what seems to be at least one logical inference, that if the soil is more compact it will allow less leaching. While it is true that this condition gives rise to a great deal more water run-off from grassland, the sediment losses, according to recent trials in Java, show grass cover to be far superior to forest in resisting erosion. While fourteen times as much water runs off from Imperata grassland as compared with softwood forest, and sixteen times as much as compared with primary forest, the sediment loss of the grassland is merely twice that of primary forest, and less than half that increment for softwood forest. ${ }^{51}$

They further complain that "the thorough cultivation of the soil that is necessary to clear the tussocks of coarse grass thoroughly aerates the soil and is thought to accelerate the decomposition of the humus." 52 This point is perhaps insurmountable. The Batak of Pusuk Buhit farmed on impeccably clean and wellaerated soil. Perhaps their methods allowed for a much-hastened and more complete incorporation of both surface and subsurface plant materials. It is certain that they cultivate a good deal more than the "top inches," where Nye and Greenland claim that there is a "chronic shortage of nitrogen." That such a shortage is not as pronounced as these authors claim is indicated by the fact that, while Freeman reported the best yields under primary forest shifting cultivation among the Iban to be sixty times the amount of seed planted, ${ }^{53}$ the lush growth in fields just

49. Sanchez, Properties and Management, p. 172.

50. Nye and Greenland, Soil, p. 11.

51. These figures are based on "Table 1. Percent run-off and average daily sediment losses from plots with constant cover, over 227-day sample period (after Kellman 1969)," in S. Manan, "The Effect of Alang-Alang Grassland on Watershed Management" (paper read at the Workshop on Alang-alang (Imperata cylindrica), Seminar BIOTROP, July 26-29, 1976, Bogor, Indonesia), p. 8. The first three entries in the table appear thus:

\begin{tabular}{lcl} 
Plot location & Percent run-off & \multicolumn{2}{l}{ Sediment loss } \\
\hline Primary forest & 0.258 & 0.20 gram /day \\
Softwood tree fallow & 0.264 & $0.29 \mathrm{"}$ \\
Imperata grassland & 3.017 & $0.40 \mathrm{"}$
\end{tabular}

Admittedly, the water run-off from grassland may wash off decomposing leaflitter. But often this litter is deposited at the base of a bunch of grass stems and the water eddies around it.

Nye and Greenland (Soil, p. 135) claim that under grass cover, erosion is promoted "on all but the most gentle slopes." This claim needs to be contrasted with the following observation by Mohr, who writes that under high forest growth "surface erosion gets less of a chance [than under grassland cover], but still the superfluous water from outside must get away and there is certainly opportunity for gully erosion. . . Consequently one finds the deepest canyons with the steepest walls in the forest tracts" (Mohr, Soils of Equatorial Regions, p. 454).

52. Nye and Greenland, Soil, p. 11.

53. Freeman, Report on the Iban, p. 252. It should be noted that there is a good deal of debate as to appropriate methods of testing for nutrients in tropical soils (see Andriesse, "Nutrient Level Shifts"). Furthermore, as Sanchez writes, "A 
opened from grassland on Pusuk Buhit, given rain, could yield eighty times, and more, the amount of seed planted, whereas with rice, on similar fields which had been in use three or more years, yields dropped to thirty times the amount of seed, and less (see Table 1).

Nye and Greenland do provide some data which might tend to explain the rise in fertility of soil under grassland fallow in tropical conditions. Writing of the Andropogoneae, the sub-Family of Graminae (the grasses), of which Imperata is a genus, they note:

8000 lbs. of dry leaves and stems will be produced [per acre] in a season but very little of this will be added to the soil, most being lost as carbon dioxide during the annual grass burn. The addition from root material is probably only one third of this amount [whereas for forest root material it is one half of the $15,000 \mathrm{lbs}$. of organic material produced in an acre.] Thus .. . in moist savannah grassland areas only about 2700 lbs. [per acre] becomes available to the soil organisms to increase the supply of humus in the soil. . . . the remainder being lost through oxidation and possibly also through leaching and erosion. ${ }^{54}$

If we accept the previously adduced observations of Pelzer that humus does not develop in tropical forest and that the biomass must be burned to release its store of minerals, it appears that there is at least some basis for believing that grassland conditions might allow greater increases in fertility levels over time relative to forest cover, in spite of periodic burnings. The most plausible explanation appears to lie in the fact that the dense mat, formed from rhizomes of Imperata and other savannah grasses, provides an organic matrix in which surface and subsurface soil is bound in a much more pervasive and compact mass than occurs under forest conditions. The biological activity taking place in this matrix would vary in accordance with temperature, moisture, soil type, compaction, frequency of cutting, burning or grazing, and the like. The growth of Imperata rhizomes is stimulated by what would appear to be adverse conditions, such as acidity of the soil, ${ }^{55}$ and cutting or burning. ${ }^{56}$ The natural ${ }^{57}$ decomposition of over-mature, parasitized, ${ }^{58}$

soil test value per se is worthless; it is an empirical number that may or may not reflect nutrient availability. Soil tests become useful only when they are correlated with crop responses ..." (Properties and Management, p. 305). In this light it is appropriate to note that the results of soil tests conducted by myself and my wife by somewhat primitive methods (using a "kit") did bear out the evidence of "crop responses" in the endeavors of the farmers. Our tests were for nitrogen, phosphorus, and potassium content, and $\mathrm{pH}$, and we found that only the former increased significantly under long-term grassland fallow.

54. Nye and Greenland, Soil, p. 50.

55. See P. Sajise, "Evaluation of Cogon (Imperata cylindrica (L.) Beauv.) as a Seral Stage in Philippine Vegetational Succession" (Ph.D. thesis, Cornell University, 1972).

56. In addition to Sajise, see also P. Granier, Y. Cabanis, F. Ellenberger, R. Razafindratsita, "Evolution des pâturages: Etude de la biologie de deux graminées Imperata cylindrica (Linn.) et Aristida rufescens (Stend), "Revue d'Elevage et de Médecine Vétérinaire des Pays Tropicaux, 30 (N.S.), 2 (1977), pp. 199227, especially 199-205. Granier et al. find that Imperata grows best when under stress, such as cutting at 5-10 $\mathrm{cm}$., burning, and grazing. They propose killing it with kindness, not subjecting it to stress, in order that the true dominant species may crowd it out. 
TABLE 1

A Comparison of Rates of Yields for Rice in Southeast Asia

\begin{tabular}{|lc|}
\hline & $\begin{array}{c}\text { Rates of } \\
\text { Yields } \\
\text { (kg/hectare) }\end{array}$ \\
Averages for Southeast Asia & \\
6 cases of shifting cultivation & 1,446 \\
7 cases of transplanting (wet-rice) & 2,185 \\
Averages for Tapanuli Batak areas & \\
Unfertilized wet-rice, Angkola & 2,870 \\
Unfertilized wet-rice, Silindung & 2,790 \\
Unfertilized dry-field, Toba plateau & 1,480 \\
Unfertilized dry-field, Dolok Sanggul & 1,560 \\
Averages for Huta Ginjang & \\
Average dry-field yields (129 fields) & 1,494 \\
By soil type & \\
Andosols (61 fields) & 1,560 \\
Regosols-lithosols ( 68 fields) & 1,435 \\
By cover vegetation & \\
Imperata grass ( 87 fields) & 1,696 \\
Mixed bush and grass (42 fields) & 1,238 \\
By length of use and cover vegetation when opened & \\
Newly opened grassland (27 fields) \\
2 or more year-old grassland (59 fields) \\
Newly opened bush-grass areas (12 fields) \\
2 or more year-old bush-grass (29 fields) \\
With respect to fertilizer use \\
Fertilized fields ( 22 fields) \\
Unfertilized fields (75 fields) & 2,095 \\
Huta Ginjang wet-rice & 1,371 \\
In Sagala valley (26 sawah) & 943 \\
\hline
\end{tabular}

a. After Hanks, Rice and Man, Table 4.2, p. 56.

b. After Mohr, The Soils, Table 96, p. 459 (from a report of Dept. L.N.H., Afd. Lb. Versl., 1927, pp. 408-10).

c. Based on data collected by the writer for 1976-77, said to be an average year, without ruinous extremes of weather or pests. Includes fifteen near-failed crops. 
or sun-dried rhizomes, in addition to what leaf litter does get incorporated as humus, and to the plant material which is essentially composted when it gets buried under a pallet of sod, all provide an increase in humus. Further nutrients are added from the ash of fires, and even from the dust of rocks struck with tools. But in the main, it is to the matrix of rhizomes which bind the soil that we appeal for the key to the grassland ecosystem, which we have found to be farmable in both short- and long-fallow conditions. In grassland, it not so much the burnt as the decayed wastes of the biomass which allow nutrient levels to rise.

Let us now review the contrast we have seen in the functioning of the ecosystems of forest and of grassland. Ultimately, speaking in generalities, it is not incorrect to say that in both cases decayed and burnt organic matter adds nutrients to the soil, and that this permits another cropping cycle in each. But the differences should by now be clear. In forest, on the one hand, nutrients are stored in the biomass, which must be burned in order to release them. In grassland, on the other hand, in spite of periodic burnings, nutrients are built up in the sod-matrix, the decay of the rhizomes of which provides a gradual build-up of humus. Burning, in addition to providing fodder, stimulates the production of additional rhizomes, which in turn decay, raising the level of humus. It is this contrast in the functioning of the ecosystems with respect to what we take to be "soil fertility" which explains why both swidden cultivators (of secondary forest) as well as grassland cultivators look to vegetational regrowth as a criterion for reusing a fallow area. Neither is thinking in our terms of "soil fertility." Both are thinking about the amount of vegetational regrowth. But there is a difference. The swidden cultivator sets out to slash and burn, and looks for ideal conditions for firing the biomass, apparently conscious of the importance of reducing the biomass to ashes, the more completely the better. The grassland farmer, on the other hand, is not particularly concerned to burn the biomass. Village women would often cut the brush and remove it to use for cooking fuel, and both men and women kept by bundles of Imperata for mulch. (Such would also have been the practice in the past, though the aim would have been to save the grass for making thatch.) The Kofyar also judge the cropping potential of grassland by the amount of regrowth of the grass, as was noted earlier (n. 35). Although Netting attempted to rephrase their perceptions in terms of soil fertility and humus content (the Kofyar say the land is "rotten" if roots come up tangled with earth), it is clear that what they are looking at is the vegetational regrowth and the degree to which the rhizomes have established a closely-bound matrix. In terms of our interpretation, both features are a sign of the subterranean processes of growth and decay of the root system of the grass. Thus, while both the forest-fallow cultivator and the grassland cultivator look to above-surface regrowth of biomass as a criterion of cropping potential, we are misleading ourselves if we imagine that both ecosystems work the same way, or that vegetational regrowth in both cases indicates degree of soil fertility. It does so indicate in the case of grassland fallow; it does not in the case of forest fallow.

57. Granier, et al. , found, by soil section of savannah, that for 250 meters of living rhizomes, there were 60 meters of "dead rhizomes" (p. 200); calculated the weight of subterranean "works" as $5,730 \mathrm{~kg} /$ hectare; and they tagged Imperata with the epithet: "cette espece souterraine" ("this subterranean species"!) (ibid., p. 205).

58. See, for example, C. N. Williams, "Sopubia ramosa, a perennating parasite on the roots of Imperata cylindrica," Journal of the West African Science Association, 6, 2 (1960), pp. 137-41. 
There are, of course, reports of small-scale grassland farming from other areas. J. C. Gerlach ${ }^{59}$ describes burning and shallow hoeing being carried out in the south and east of Borneo which, he notes, may be in imitation of a more intensive hoeing method practiced there by Javanese migrants. A recent account of Javanese migrants in Lampung, South Sumatra, also describes their methods of eradicating the grass, though by methods less intensive and less successful than those which are practiced on Pusuk Buhit. ${ }^{60}$ Barton ${ }^{6 I}$ cites the recollections of two Ifugao informants whose hands were cut through not holding tightly enough while pulling the grass when, as children, they were helping their parents make sweetpotato gardens. Evans-Pritchard ${ }^{62}$ shows a picture of a man performing such a task. Most, if not all, of these cases may be considered "incipient" grassland farming, because the grass is not eradicated from the plot under cultivation, and it is bound to resprout and send out additional rhizomes during the growing season, which would seriously limit crop yields.

Cases of "integral" grassland farming appear to be rare. Even the Batak who provided the impetus for this study had other methods, including irrigated rice. The Kofyar ${ }^{63}$ have both semipermanent cultivation on manured fields as well as shifting cultivation of bush and grassland fallows. However, from the report of W. C. Clarke, ${ }^{64}$ the Batainabura of the central highlands of New Guinea, living in an area which is almost entirely grassland (including Imperata), "garden" it successfully. They cut and burn it, then turn the soil and work it into mounds, "a process that may be repeated consecutively for several years before the plot is abandoned to a short fallow period [five to ten years?] under grass." 65 Even they have "a few rough forest gardens," and so cannot rightly be said to farm solely grassland. The Batak, the Kofyar, the Batainabura, and others like the Kapauku, ${ }^{66}$

59. J. C. Gerlach, "Bevolkingsmethoden van ontginning van alang-alang-terreinen in de Zuider en Oosterafdeeling van Borneo," Landbouw, 14 (1938), pp. 446-50.

60. M. Suryatna and J. L. McIntosh, "Food Crops Production and Control of Imperata cylindrica on Small Farms" (Paper read at the Workshop on Alang-alang [Imperata cylindrica], Seminar BIOTROP, July 26-29, 1976, Bogor, Indonesia).

61. R. F. Barton, Autobiographies of Three Pagans in the Philippines (New Hyde Park: University Books, 1963), pp. 46, 215.

62. E. E. Evans-Pritchard, The Nuer: A Description of the Modes of Livelihood and Political Institutions of a Nilotic People (New York: Oxford University Press, 1969 [1940]), p. 79, Plate XI B. This seemingly placid scene takes on quite another aspect if the blurred arms are noticed, and the grass is identified as what it appears to be, Imperata.

63. Netting, Hill Farmers of Nigeria.

64. W. C. Clarke, "From Extensive to Intensive Shifting Cultivation: A Succession from New Guinea," Ethnology, 5 (1966), pp. 347-59, esp. pp. $353 \mathrm{f}$.

65. Ibid., p. 354. See also his comment, p. 356, on Nye and Greenland, Soil.

66. L. Pospisil, The Kapauku Papuans of West New Guinea (New York: Holt, Rinehart and Winston, 1963), pp. 7-8. Pospisil describes "intensive shifting cultivation" on grassland, in which the grass is cleared "by uprooting and burning it ..." on the valley floor; typical bush-fallow shifting cultivation on the mountain slopes; and a third method he calls "intensive complex cultivation," involving "a laborious turning over of the soil with a spadelike tool," and the making of beds which are provided green manure and compost. 
do successfully eradicate Imperata when they set out to do so in a given plot; they have at least "integral" subsystems of grassland farming. The Kachin also merit attention in this regard.

Congruence and Anomaly in the Ecological "Holdings" and Political Organizations of Batak and Kachin Communities

Two such dissimilar reinterpretations of Leach's Political Systems of Highland Burma as those of A. T. Kirsch on the one hand, and J. Friedman, on the other, ${ }^{67}$ both use the demographic limitations of a swidden system as determinant of the limits on the degree of social cohesion attainable in "hill tribe" society (however differently they conceive that quality). Admittedly, both give passing mention to the practice of "some" wet-rice farming by mainland Southeast Asian hill tribes, and Friedman mentions grassland farming among the Wa.

Leach explicitly notes the existence of a third type of farming among the $\mathrm{Ka}$ chin, which he calls "grassland taungya" (taungya, Burmese for slash-and-burn). In fact, although Leach unfortunately describes the Kachin methods of cultivating grassland only briefly, the overall picture which he gives of Kachin agriculture bears great similarity to the Batak case. Both peoples apply similar methods to the maintenance of similar ecological "holdings." 68 Kachin grassland farming is not of the incipient sort that has been noted with respect to areas of Borneo, South Sumatra, and Luzon. ${ }^{69}$ Indeed, Leach describes the characteristic forms of Kachin agriculture in clear enough terms for it to be something of a mystery that the usual stereotype of "hill tribes" as swidden agriculturalists could have persisted. The description given in his brief essay, "Some Aspects of Dry Rice Cultivation in North Burma and B ritish Borneo," 70 was repeated and expanded in his Political Systems, though with one significant minor omission. In the earlier essay, Leach wrote:

A Kachin village in North Burma . . . cultivated rice in four different ways. These different methods were complementary to one another, rather than alternative. . . The Kachin preferences for different types of cultivation were obvious. Irrigated wet rice with animal traction was

67. A. T. Kirsch, Feasting and Social Oscillation: Religion and Society in Upland Southeast Asia, Southeast Asia Program Data Paper No. 92 (Ithaca: Cornell University, 1973); J. Friedman, "Tribes, States and Transformations," in Marxist Analyses and Social Anthropology, ed. M. Bloch (New York: Wilcy - 1975).

68. Hanks defines the ecological "holding" as follows:

"We shall call the total of these active working relationships needed to produce and maintain an environment for man as agriculturalist a 'holding.' Without the plowing, harrowing, and weeding . . . without the shelter that the cultivator builds and the societal arrangements that bind him to his neighbor, the crop would be impossible.

"A 'holding' differs from a 'niche' in that it presumes active work by man to transform, maintain and thus to utilize the natural environment. . . . [M] an's holding alters the environment for the plants he raises as well as for himself. . . [ [R] elationships in a holding exceed the limitations of the word 'niche,' which a plant or animal transforms at its own peril . . . [although] each holding 'rests' upon a niche." (Hanks, Rice and Man, pp. 45-46.)

69. See above, $\mathrm{nn} .59,60,61$.

70. Appearing in Advancement of Science, 6, 2 (1949), pp. 26-28. 
recognised as much the most advantageous; anyone possessing such land was rated a rich man. Hkaibang grassland cultivation came next. Ordinary jungle taungya was rated rather lower than hkaibang in popularity. Most striking however was the low esteem in which wet rice land worked by hand was held. This evaluation was clearly based upon considerations of labour effort rather than of gross yield since it was fully recognised that a better yield per bushel of seed could generally be expected from any form of wet rice as compared with dry. ${ }^{71}$

What has gone unnoticed in subsequent discussions of the Kachin is the fact that grassland was preferred to "ordinary jungle" slash-and-burn for dry-field farming--much as it was among the Angkola Bataks Junghuhn described in 1847. Leach omitted to note the fact in his subsequent book on the Kachin, and instead pointed out that the forms of agriculture were associated with decidedly different "ecological zones," and that grassland, the cultivation of which he had now come to malign, was largely associated with the drier zones:

I propose to distinguish three types of hill agriculture which I shall call (a) monsoon taungya, (b) grassland taungya, (c) irrigated hill terraces. . . . The term taungya (hill field) is a Burmese term which describes a technique resembling . . . ladang in the literature of Malaya. . .

Zone $\mathrm{A}$ is typical monsoon forest country. . . .

Zone $B$ is more or less outside the monsoon area. . . .

In general, grassland taungya of the ordinary Zone B type probably deserves much of the condemnation implied in [the typical robber-agriculture criticism of] Spate. A village which relies exclusively on such taungya can seldom be self-sufficient in foodstuffs. There is consequently a much more marked tendency in Zone $B$ than in Zone A for the hill villages and valley villages to be interlocked in some sort of more or less permanent economic and political interdependence.

In terms of climate and ecology, Zone $C$ is intermediate between Zones $A$ and $B$, as [the fact that north slopes are forested, south slopes are grass clad] clearly shows. The Kachins of this area practise both monsoon and grassland taungya, but, in addition, in a number of widely separated localities one finds elaborate systems of irrigated terracing used for the cultivation of wet-rice. ${ }^{72}$

As in Hagreis' use of the term "ladang, " ${ }^{73}$ to characterize Batak grassland farming, and Mohr's use of the Philippine term "kaingin, " ${ }^{74}$ for the same purpose, the use of "taungya," from the Burmese, risks causing misunderstandings, both as concerns the methods of farming and the ecological parameters involved. The

71. Ibid., p. 27 (emphasis added).

72. E. R. Leach, Political Systems of Highland Burma: A Study of Kachin Social Structure (Boston: Beacon Press, 1965 [1954]), pp. 22, 24, 26, 27; also his Map 2 "Ecological Zones" (p. 23). Friedman claims that these "zones" were man-made, rather than climatically co-varying. (He imagines that the monsoons are affected by ground cover.) The "zones" are, however, not one or the other, though climate largely determines the "niche" in which people establish and maintain a holding.

73. Hagreis, "Ladangbouw."

74. Mohr, Soils of Equatorial Regions, p. 457. Mohr appears to have been unaware that any grassland was farmed, although his own Plates of the Karo region (Figures 174 and 175) clearly show dry-rice flanked by Imperata. 
phrase "grassland farming" recommends itself as a means of more clearly differentiating the practice from shifting cultivation of secondary forest or jungle.

Although the climatic zones and the farming systems that are used in each are not nearly so well demarcated in the Batak areas as in the Kachin, it is remarkable that, among the Kachin also, irrigated wet-rice is farmed in even the driest zone, while in the wetter zone where most slash-and-burn is done, the pattern is "monsoon taungya in the hills; wet rice in valleys. . . ." 75

A similar distinction could be drawn between the relatively dry Samosir region and the Dairi Batak area which lies west of the lake crater and receives much more rainfall. Leach goes to some lengths in examining the degrees of correlation between given ecological niches (and the holdings maintained therein) and political organizational forms. ${ }^{76} \mathrm{He}$ is forced to conclude that there is no correlation to be discerned between the culture and political organization of Kachin communities and the ecology :

. . Differences in the physical environment provide only a partial explanation for differences of cultural and political organization. Ecology can to some extent explain why, if Kachins choose to live in the inhospitable terrain of the Hpimaw Pass, their technical organization and pattern of settlement should be what it in fact is among the Lashi of that region; it does not really explain why the Lashi should choose to live there at all when there is plenty of better land elsewhere, nor does it explain why the Lashi should have a gumlao organization when the Atsi of the Sadon area, practising similar techniques under somewhat similar conditions, are gumsa. ${ }^{77}$

Leach comments that:

a village which relies exclusively on [grassland farming] can seldom be self-sufficient in foodstuffs. There is consequently a much more marked tendency in the [dry zone than in the wetter jungle zone] for the hill villages and valley villages to be interlocked in some sort of more or less permanent economic and political interdependence. ${ }^{78}$

This is certainly applicable to the Toba Batak case of Huta Ginjang. The problem is that such economic and political interdependence does not lend credence to

75. Leach, Political Systems, p. 232. He adds: "In the immediate pre-British period the wet rice production areas throughout the zone were controlled politically by Kachins but cultivated by Shans and Assamese 'slaves.'" Perhaps because in the monsoon-forest western areas it was Shans and "slaves" who farmed the irrigated valleys--although clearly the Kachins themselves do so in the intermediate and dry zones--Kachin farming of wet-rice and, particularly, of grassland have gone largely ignored in subsequent discussion.

76. See ibid., pp. 18-28, 228-38.

77. Ibid., p. 238. Leach (ibid., p. 57) gives these glosses of the terms the Kachin apparently distinguish as separate "types of political organization":

"Kachin gumlao--a 'democratic' species of organisation in which the political entity is a single village and there is no class difference between aristocrats and commoners,

"Kachin gumsa--an 'aristocratic' species of organisation. The political entity is here a territory called a mung . . . which has as its head a prince of aristocratic blood . . . who assumes the title Zau (cf. Shan Sao)."

78. Ibid., p. 26. 
Leach's theory of the oscillatory nature of Kachin organization. Note that, according to Leach, the gumsa ("feudal/aristocratic") political organization predominates in the zone of the wetter jungle-taungya, whereas gumlao-type ("democratic") organization seems to have persisted throughout most of the drier, yet demographically denser, northeastern areas, regions both of predominantly wet-rice and of grassland farming. This "political" fact seems to throw into question the previous remark on grassland's leading to "interdependence." Why should the swiddenfarming hill-Kachin of the western regions have maintained autocratic control over other Kachin and the valley Shans in conditions of demographically low density, while in (what are usually considered the more ecologically deprived) areas of grassland, hill villages established interdependent (or mutually reciprocal) relations with, but were themselves not subordinated to, their apparently more economically advantaged valley cousins? In other words, it seems somewhat mysterious that political organization of the gumsa type is not more prevalent among Kachin who live in the more demographically concentrated wet-rice intermediate zone, but is the dominant type in the monsoon forest region where slash-and-burn (and, implicitly, low population density) is the norm.

At least a partial answer is implied in Leach's statement that "a gumlao community, unless it happens to be centered around a fixed territorial centre such as a patch of irrigated rice terraces, usually lacks the means to hold its component lineages together in a status of equality." 79 Apparently what is intended is that being tied down to a fixed territorial center, with provision for at least a modicum of livelihood, makes it possible for social equilibrium to be established.

This seems a suitable description of what the Toba Batak of the Samosir region have achieved, through their ecological holding, the social organization of their livelihood (including "farming"), and a process of hiving-off, outmigration.

Leach's gloss of the ideal type of Kachin gumlao--"a 'democratic' species of organization in which the political entity is a single village and there is no class difference between aristocrats and commoners"--recalls the anarchic political scene with which the Dutch had to contend when they sought to govern the Toba Batak through "native rulers." ${ }^{80}$ The huta (hamlet or village) were each autonomous insofar as their own internal affairs were concerned. As Vergouwen wrote:

In Toba the internal differences between the villagers result from and are dependent on the foundation of the village. Once a man has founded a village, mamungka huta [lit., "to open" a village] whether he did it alone or (seldom) with the cooperation of others, he creates for himself and for his sons a community of its own . . . and it is held in perpetuity by his descendants so long as they continue to dwell in the village. . . . ${ }^{81}$

Viewed from the outside, then, the Toba Batak, with their plethora of small, independent villages, appear to have a "democratic" organization. On Samosir, nearly all chiefs or headmen "laid claim to the few chieftaincies which the Dutch

79. Ibid., p. 204.

80. In addition to the references below, see L. Castles, "Tapanuli: The Political Life of a Sumatran Regency, 1915-1940" (Ph.D. dissertation, Yale University, 1972), especially Chapter 7, "Harajaon Politics in North Tapanuli." Much of this work on the Bataks' absorption in parochial conflict rather than an awakening nationalism could be read in the above light.

81. J. C. Vergouwen, The Social Organisation and Customary Law of the TobaBatak of Northern Sumatra (The Hague: Nijhoff, 1964 [original Dutch publication, 1933]), pp. 111-12. 
government had instituted." 82 The contrast between the Toba area and South Tapanuli is also significant: "One does not find social classes in the Toba Country such as exist in South Tapanuli. . . " 83 Again, speaking first of the Toba, Vergouwen writes, "Peonage in any form was forbidden after the establishment of the Netherlands Indies Government and all traces of its having existed have now been expunged, except in South Tapanuli where the social structure which existed in olden times has, up to now [1933], prevented a complete merging of the freed and the free." 84

If it may be granted that the above correlations have been drawn solely for descriptive purposes rather than to endorse the particulars of Leach's interpretation of hill tribe social dynamics, we are at liberty to agree that--as he says of the Kachin, so too for the Batak--"there is no direct correlation between ecology [or ecological holding] and cultural or political organisation." The Simalungun Batak area, with swidden and grassland farming, had small kingdoms ${ }^{85}$ (comprising up to 10,000 people). But the "political organization" of the Angkola Batak, who farmed both wet-rice and grassland, also resembled Leach's gumsa pole; while the Toba areas, especially the Samosir region, with holdings of wet-rice, grassland, and bush fallow, appear to have been "democratic."

A great many other correlations of Kachin and Batak practices, as well as of their beliefs, are, of course, possible. Leach ${ }^{86}$ has led the way in providing an extensive list of "corresponding structural characteristics" of the two societies, and he deems Batak society, "a kind of structural duplicate of that of the $\mathrm{Ka}-$ chin." ${ }^{87}$ In our depiction of the elements of their systems of agriculture, we have simply added further congruences, a set of parallels in the types and preferred order of application of their agricultural methods found in the maintenance of similar ecological holdings which have been assumed to "rest" on similar "niches"; and we have noted a lack of correspondence between ecological holding and "political organization" in both societies.

It would be overly ingenuous, here, to fail to acknowledge that the abovementioned congruences, occurring as they do in societies which have been described as "structural duplicates," can easily be accounted for by the cultural materialist doctrine put forward by $M$. Harris as a "principle of techno-environmental, techno-economic determinism," viz., that "similar technologies applied to similar environments produce similar arrangements of labor in production and distribution, and that these in turn call forth similar kinds of social groupings, which justify and coordinate their activities by means of similar systems of values and beliefs." ${ }^{8}$ "The problem, of course, is to define that 'similar," as Bennett put it:

.. Which factors are marginal, which are critical? . . The issue is not whether determinism exists, but precisely how much and in what institu-

tions. . .

82. Ibid., p. 126 .

83. Ibid., p. 110.

84. Ibid., p. 327.

85. R. W. Liddle, Ethnicity, Party and National Integration: An Indonesian Case Study (New Haven: Yale University Press, 1970), pp. 20-21.

86. Leach, "Structural Implications," pp. 91-94.

87. Ibid., p. 90.

88. M. Harris, The Rise of Anthropological Theory (New York: Crowell, 1968), p. 4 . 
The response of a particular farming population to a particular environmental configuration is compounded of technoeconomic factors, resource parameters, innovations contributed by external sources, cultural styles of management, consumption preferences, rituals, food tastes, transportation facilities, and settlement patterns. . . ${ }^{89}$

Besides the differences among the various Batak subtribes (each, incidentally, with its own dialect), we can point to other hill tribes in Southeast Asia which are as much structural duplicates of the Kachin as are the Batak (for example, the Chin ${ }^{90}$ ), and who, by Lehman's wide-ranging account, do not farm on grassland. On the other hand, the Kofyar of Nigeria farm grassland and bush fallow--and even some wet-rice, though without irrigation--as well as semipermanent "homestead fields." But they live in patrilineally inherited homesteads rather than in villages as do the Southeast Asian hill tribes. And a careful reading of any combination of Stevenson, Lehman, Freeman, Conklin, Barton, and Leach can uncover so many similarities and differences that the project of deciding which are to be considered independent and which dependent, which critical and which marginal, would either get bogged down in detail, or engage merely in what Bennett terms "broad generalities." 91

\section{Recapitulation: The Agricultural} Ecology of Grassland Farming

The above lines of reasoning on the ecosystems of forest versus grassland fallow have not been undertaken merely to begin to make the case for the possible practical ecological and economic bases of the grassland component of Batak agriculture. The arguments have also been made because the implications of the system have gone largely unremarked in descriptive and theoretical works on both the ecology and political economics of Southeast Asia. A framework of reference to ecological matters and to political economy is as necessary to an adequate analysis of the social organization of livelihood in Batak village society as is a decent model of the ecosystem of grassland. From a cultural ecological and economic point of view, though, even if there is an agronomic basis for the practice of grassland farming, and if integral agricultural subsystems based on it are found elsewhere, we have only the beginnings of an adequate explanation of the singularity of the Batak example in terms of stereotypical adaptive strategies of Monsoon Asian populations. It has been the ideal types, either wet-rice or shifting cultivation--and never grassland--which have been taken as keystones both for social anthropological analyses and for the teaching of ecology; for example, in the training of those in the administrative hierarchies of agricultural and forestry departments. But, given the similarities between the range of Batak and Kachin ecological holdings and their preferences in maintaining them, it may be asserted that, insofar as their shared "anomaly" (grassland farming) has yet to be taken into account in

89. J. W. Bennett, The Ecological Transition: Cultural Anthropology and Human Adaptation (New York: Pergamon Press, 1976), pp. 231-32.

90. See F. K. Lehman, The Structure of Chin Society (Urbana: University of Illinois Press, 1963), especially pp. 88-102, 122-56; E. R. Leach, "Kachin and Haka Chin: A Rejoinder to Levi-Strauss," Man(N.S.), 4 (1969), pp. 277-85; Kirsch, Feasting, pp. 40-41, has categorized many features in Tables.

91. Congruences and differences of greater and lesser degrees would also emerge from a comparison of Batak, Kachin, and Kofyar (for example, their ideas about the class of relative to suspect as witches are disparate). Space is the limiting factor, however, and we will refrain from making the attempt here. 
ecological or political-economic analyses, a great deal of the previous body of assumptions concerning the so-called carrying capacities of both their ecological holdings are put in doubt. Hanks' remark that Imperata signals "the terminal point for shifting cultivation, for though settlements may continue, economies must change to other techniques of cultivation . . ." 92 is certainly apposite. We have touched briefly on the existence of complementary agricultural subsystems in the ecological holdings of Batak and Kachin. Both have the striking preference of building irrigable terraces for the growing of wet-rice; ${ }^{93}$ and we have been led to confront their equally striking second preference for grassland farming of dry rice. In the Toba case, grassland fields are worked and fallowed on a shifting basis, that is, in a pattern characteristic of their conventional swidden, with longer fallow than cropping. In the case of the Toba Batak of Pusuk Buhit, in addition to wet-rice, grassland-, and bush-fallow cultivation, we have also noted the replacement of some wet-rice by continuous or semipermanent cropping, in irrigable and nonirrigable fields, of both annual and perennial crops, with the use of manure and mulch. As Leach has said of a Kachin village in north Burma, it appears that there is an amalgam of complementary agricultural subsystems, including grassland farming, that has developed and been sustained--in part, at least--because a fair number of the inhabitants chose to remain at a "fixed territorial centre, a patch of wet-rice terraces." 94

Part of the reason that they "allow" fallows to progress from bush to grassland (or protect grassland from turning into forest), lies in the probability that, as has been argued, the grassland ecosystem is not so irrevocably degraded as we had been led to believe.

It can be said that, in some sense, grassland is protected from progressing through bush to forest fallow. This is implied by the contention of Granier, et al. ("Evolution des pâturages"), that, under "normal" or "natural" conditions, ungrazed, unfired grassland must eventually give way to more competitive species' dominance. Of course, the major charge against swidden has always been that fires prevent the regeneration of forest. What Granier et al. are actually implying is that Imperata and bovine livestock are symbiotically related to each other through the medium of fire, that is, through human mediation. As Hanks puts it, "man's holding alters the environment for the plants he raises as well as for himself ..." 95 and, obviously, for his livestock.

Now, taking a somewhat different point of view from the usual one, the advent of grassland may be said to herald a beneficial adaptation; it may serve useful purposes in the maintenance of the total ecological holding, in spite of the fact that establishment of an initial holding through slash-and-burn cultivation may have been responsible for having deforested the area in question. For instance, of the "integral swidden"-cultivating Hanunóo, Conklin writes that, while they never clear a new swidden "in an area largely covered by grasses" (since they do not use soil-turning techniques), the grasses are "unique in that within the context of the swidden cycle [Imperata and other grasses] are exterminated as weeds,

92. Hanks, Rice and Man, p. 31 .

93. . . . and for the Batak, non-irrigable terraces for growing dry-rice and other crops as well.

94. For the inhabitants of the flanks of Mount Pusuk Buhit, a tie to a genealogical center, a point of origin beyond reproach, ought also to be considered in a fuller presentation. See reference to Si Raja Batak, above.

95. Hanks, Rice and Man, pp. 45-46. 
while outside that context they are either protected and consumed as economic necessities (e.g., for thatching) or used profitably as means to other economic ends (e.g. , for grazing)." 96

Viewed in this perspective, the positive and adaptive features of grassland for the maintenance of an ecological holding of which it is a component can be seen to be of substance. The factors which favor the greater or lesser degree of dominance of grassland in many locales may, it should be kept in mind, have as much to do with climatic and agronomic givens (for example, windward or lee situation of a field, bedrock, soil qualities, $\mathrm{pH}$ of the soil or presence or absence of limestone formations). Nevertheless, from what we have learned concerning the symbiotic relationship between the grass and livestock, mediated through man, the husbander and setter of (most) fires, we may state the following: deforesting reduces predation, permits grazing, admits the possibility of growing food, and provides a setting practical for looking out for attack. A grassland cover appears to be equally good for farming, though it may require different energy inputs. The preference of Kachin and Batak who farm it in lieu of forest is not surprising, given the labor involved in cutting down large trees prior to the chainsaw.

The analyses set out in this article are not intended to pose a problem (of the congruence of Batak and Kachin methods and preferences) requiring a solution, but to clarify the ecological parameters within which it will be fruitful to base future study of the cultural diversity of hill tribe belief systems and, particularly, of Batak social organization of livelihood as it relates to their system of beliefs.

Taking a broader view of the ecological holding maintained by the Batak of much of North Sumatra, we may say that implicit in the labor expended in the physical alteration of the environment in the building of both the dry and wetfield terraces, and of what amounts to a system of deforestation near settlements, is a desire for permanent settlements, and the ability to maintain them in a permanent socio-cultural developmental cycle, and therefore a tendency to high demographic concentrations. But, having found that the ecological holding of the sedentary rotating- and permanent-field agriculture of this society implies a high demographic concentration relative to shifting cultivation, we are still left with the question of what it is in the society which leads people to exploit and enables them to succeed in their holding. It would appear that any answer that is even remotely satisfactory would have to result from a much more penetrating analysis than has been attempted here of the social and cultural givens of the society which has entrenched itself, by its variegated holding, in the ecological "niche" provided by deforested grassland.

96. Conklin, Hanunóo Agriculture, pp. $128 \mathrm{f}$. Other authors who have remarked on these uses are H. Schrauwen, "Alang-alang in dienst der veeteelt," Algemeene Landbouw Week'lad, 16, 22 (1931), pp. 605-6; I. H. Burkill, A Dictionary of the Economic Products of the Malay Peninsula, vol. 2 (London: Crown Agents for the Colonies, 1935); D. Brown, "Grazing and Fodder Value," and "Other Uses," in Imperata cylindrica [see n. 41], pp. 27-44; Lehman, Structure of Chin Society, p. 9; M. Soerjani, Alang-alang: Imperata cylindrica (L.) Beauv: Pattern of Growth as Related to Its Problem of Control (Bogor: Biotrop Bulletin [SEAMEO] 1, [1970]); D. S. Simandjuntak, "Mendayagunakan alang-alang," Warta Pertanian, 2, 15 (1972), pp. 38-41; "Alang-alang sebagai lawan dan kawan," Menara Perkebunan, 29, 2 (1960), pp. 23-27; Netting, Hill Farmers of Nigeria, p. 182; Suryatna and McIntosh, "Food Crops Production"; Sanchez, Properties and Management; and J. Fox, Harvest of the Palm: Ecological Change in Eastern Indonesia (Cambridge: Harvard University Press, 1977), p. 45. 


\section{Conclusions: Some Implications for Development Planning}

On the basis of the arguments in this article, it should be clear that the largescale planting of forest on steep land used as pasture by a sedentary population is misdirected. Happily, in addition to reforestation programs, Indonesia also has national programs for the improvement of food-crop yields, and these may be considered more important than those of reforestation. Several thousand households live on the flanks of Mount Pusuk Buhit, and destroying their present mode of livelihood by forbidding them to burn their pasture-lands, before insuring that a better one would then come into being, ${ }^{97}$ seems to be a dubious enterprise. This is all the more the case when one considers the figures for land-use in Indonesia. From Suryatna and McIntosh we learn that:

The total land area of Indonesia is about 202 million hectares. It is estimated that 120 million hectares are in forest, 64.5 million in grassland consisting mostly of alang-alang (Imperata cylindrica (L.) B eauv.) and 17.5 million in crop land. Furthermore it is estimated that among all the Islands except Irian Jaya there are 55 million hectares of land suitable for cultivation . . . roughly 37 million hectares of land potentially suitable for crops but presently not in production. . . (1974. World Bank, Vol II, Annex 2.)...

The magnitude of the land area abandoned to alang-alang and bush but considered to be suitable for cultivation is usually estimated to be 20 million hectares. Data from 1970 indicated a total area of 5.8 million hectares of lowland paddy. Of this only 4.1 million hectares received some irrigation while the rest was swamp and rainfed lowland rice. If we include double cropping . . . about $94.4 \%$ of the rice production comes from this lowland paddy . . . only $10 \%$ of the 55 million hectares of land suitable for cultivation outside of Irian Jaya. ${ }^{98}$

It should be added here that about 25 percent of the forest, or 30 million hectares, have been contracted out for exploitation to domestic and foreign companies, according to the Director-General of Forestry, Soedjarwo. ${ }^{99}$ Even if tens of thousands of hectares more of traditional pasture-land in the area of Lake Toba were planted in pine forest, it would not begin to compensate for negligence on the part of the timber companies.

Suryatna and McIntosh go on to make an interesting proposal:

The area for future expansion of irrigated land and even rain-fed lowland rice is limited. . . . In contrast to the expensive and time-consuming development of irrigation and drainage schemes, upland crop production could be started immediately and with little investment. There are approximately 18 million hectares of flat to rolling land between the mountains and coastal swampy lowlands in Sumatra. . . Much is abandoned to alang-alang. The question that the agriculturalist must ask

97. For example, if they devoted their energies to tapping pine-resin for the production of turpentine on a plantation subcontracted to a Chinese exporter like C. V. Muda Jaya, Kecamatan Habinsaran, Kampung Matio, where 400 households with four workers per household realized (as of 1978, according to the contractor) Rp. 21,250 per month per household $(\$ 51.00)$ on a concession of some 5,000 hectares.

98. Suryatna and McIntosh, "Food Crops Production," pp. 1-2.

99. Report in Sinar Indonesia Baru, March 2, 1978, p. 6. 
himself is this--Can this vast area of land which is presently not used, or at least underused, be profitably cultivated for food-crop production for a sustained period of time? ...

There are two very important factors which have encouraged us to consider the red-yellow podzolic soils which predominate in the shifting cultivation areas as potential rather than problem soils. First of all in these areas the rainfall usually exceeds $200 \mathrm{~mm}$ for at least six months of the year. . . Generally cassava and other drought resistant crops can grow during drought periods.

The second important consideration is that these soils are responsive to fertilizer and do not possess unusual "fixing capacities" or nutrient element deficiencies. Consequently it seems reasonable that we could increase the fertility of the soil by judicious use of fertilizer and maintain it by returning as much of the residues (as straw . . . or as stable manure) as possible. 100

They propose two cropping systems for transmigration areas (with specific reference to Lampung, South Sumatra): a perennial-crop system and a food-crop system, with both mixed-cropping and relay-cropping.

A system which combines both of the above, as well as both types of cropping, is already in operation among the mostly dry-field farming Toba Bataks of Pusuk Buhit and much of the area of Samosir. Coffee is the main perennial crop while shallots and garlic and also rice are the main commodities (in addition to supplementing the traditional net export of livestock to Dairi and elsewhere). Yam and cassava, as well as taro and corn, are also important both for human sustenance and as food for nonbovine animals. Unfortunately farmers do not have access to the seed or the capital, nor could they afford the labor which would be required to bring an average of two hectares per houshold under "forage grasses and legumes" to support their livestock, as the agronomists propose be planned for the transmigrants of Lampung.

But perhaps it is unnecessary to do so. Map III A, below, is from the most recent (1972) "Landuse" map of the Interior Department of Indonesia. ${ }^{101}$ If it is any indication of the information available to government planners, then such information appears to be erratic. According to the map, Huta Ginjang is surrounded by hutan penggembalaan (hutan alang-alang), that is, pasture-forest (Imperata jungle). (The location of the village is shown by a small dot, four V's to the left, above the A on Pusuk Buhit.) But an administrator, looking at this map, without personally studying the livelihood of the inhabitants of the place marked by a dot that seems to be a misprint, would be misled. He might order--it has come to the writer's attention that is now in process--much of the pasture to be planted in trees. An accurate map, however, would show something along the lines of Map III B. It is neither ladang (as the Map puts it, "shift cultivation") nor is it simply tegalan (dry-field, nonirrigated) dry field farming that goes on. It is neither and it is both. And as soon as a field grows up in a fallow, it becomes common pasture, de facto. The process of return to grassland, if it is allowed to occur, takes about two years. But as soon as two or three weeks after rice has been harvested, one sees horses and cows allowed to clamber about accessible (even terraced)

100. Suryatna and McIntosh, "Food Crops Production," pp. 2-3, 6. Farming on Pusuk Bukit is of soils classified as Regosols, Lithosols, and Andosols. See D. L. Bramao and R. Dudal, "Tropical Soils," in Proceedings of the Ninth Pacific Congress, pp. 47-49; and Mohr, Soils, pp. 454-55.

101. Direktorat Landuse, Departemen Dalam Negeri, Sumatera Utara, Lembar $12 \mathrm{AH}$. 
MAP II I A

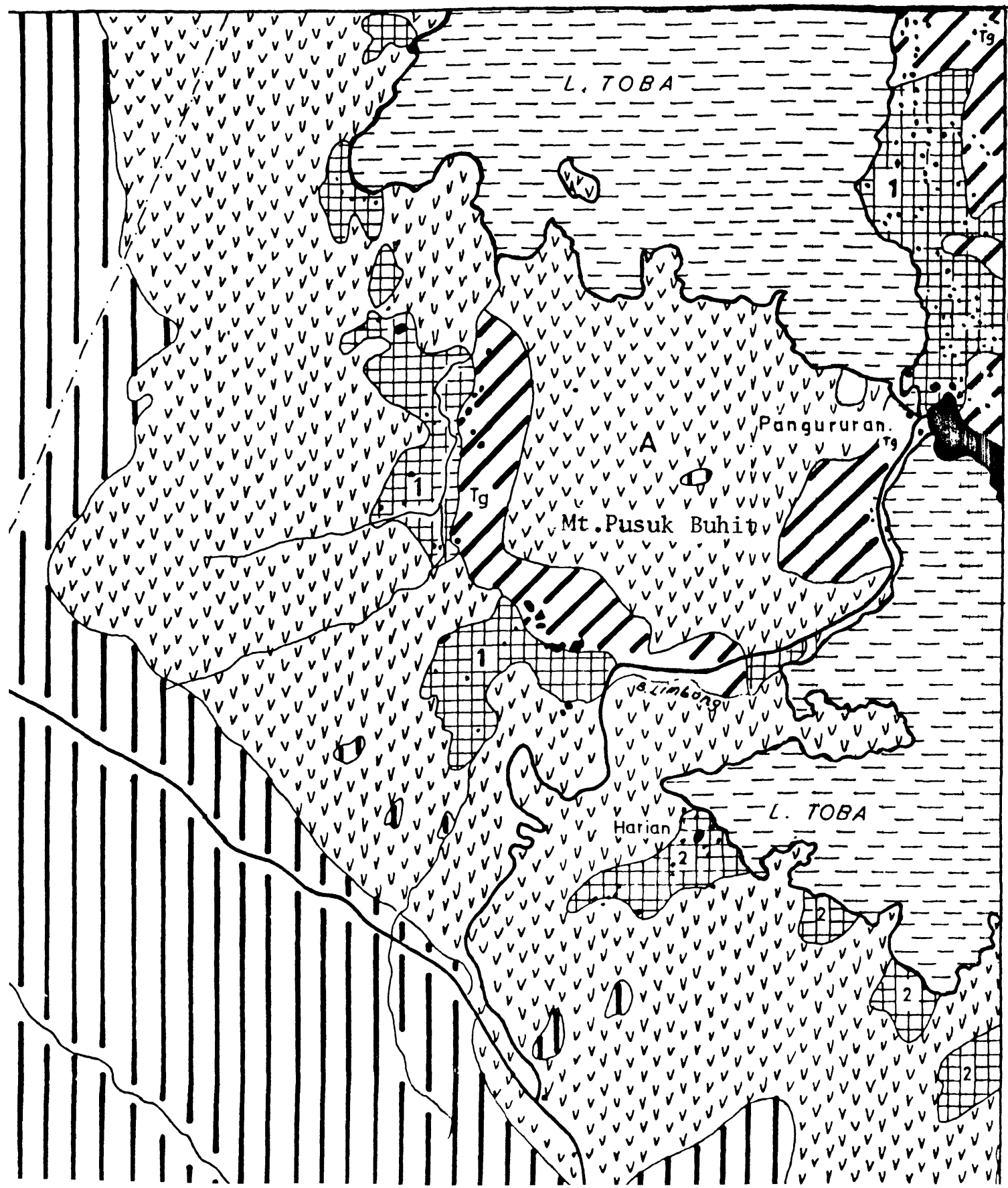

Hutan Penggembalaan: (A Hutan alang-alang)

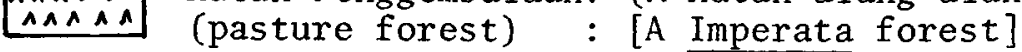

Tanah Tandus

(barren soil)

Hutan Lebat

(heavy forest)

Pertanian Tanah Kering 'Tg = Tegalan Ls = Ladang (shift-cultivation). (Dry-field farming) (Tg = not irrigated) [Ls $=$ swidden

Sawah dengan pengairan $2=2$ kali setahun $1=1 \mathrm{kali}$ padi setahun (irrigated wet-rice) $\quad(2=2$ times a year $)(1=$ once a year $)$ 


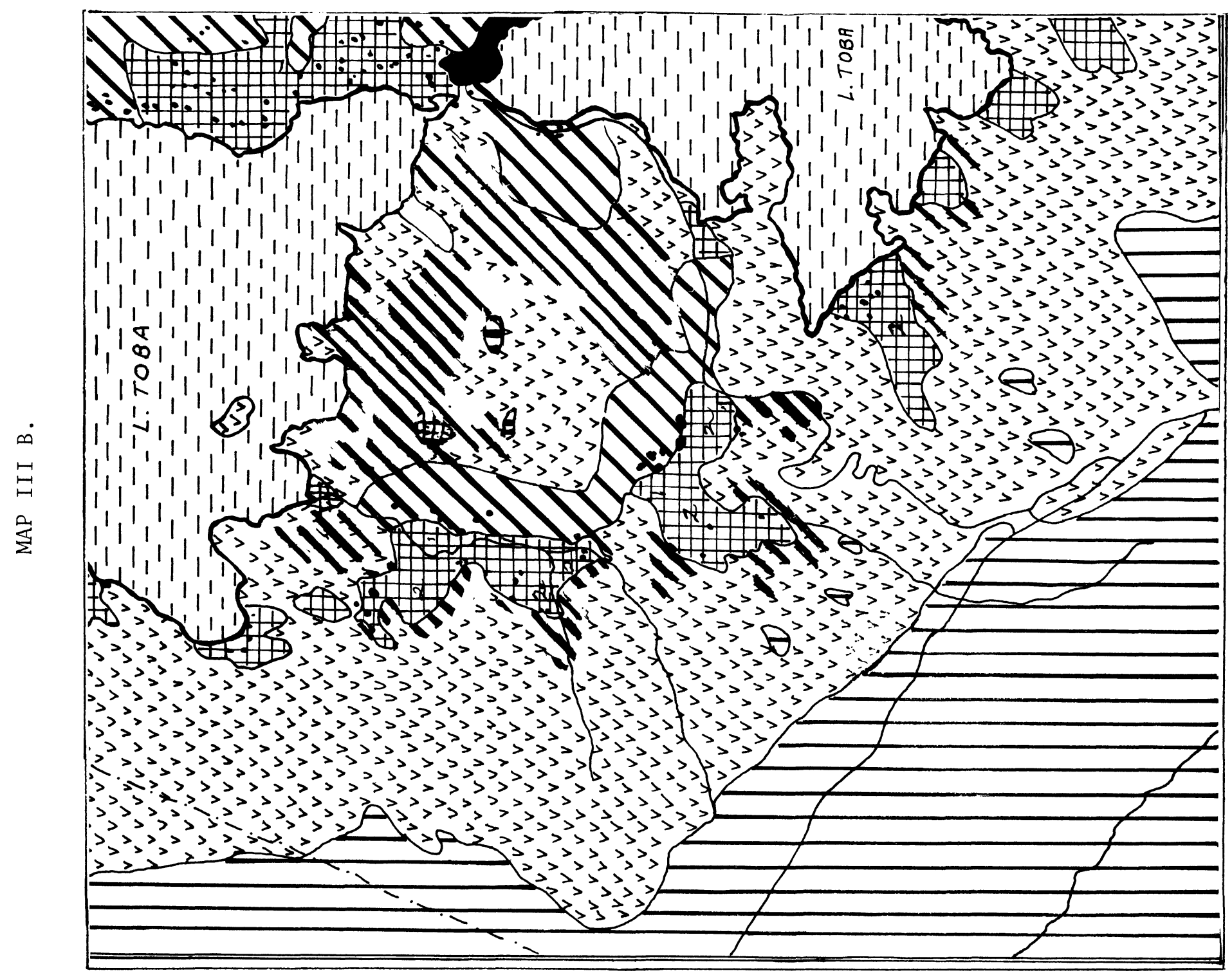


fields with impunity. Under Imperata grassland fallow, as under less advanced weed covers, what is fallow is not simply "waste land" or "empty land." It produces fodder constantly, and it regenerates soil fertility when conditions are favorable for the dominance of Imperata, that is, when men set fires and graze their livestock.

But let us end on an up-beat note. The land use map, III A, is a definite improvement over the map imagined by Dutch topographers. Having no way to show shifting grassland farming on terraces, they designated the whole mountain to be Imperata. 
APPENDIX I. THE BOTANICAL SUCCESSION TO PASTURE: NOTES ON THE EARLY STAGES

Hedy Bruyns Sherman

\begin{tabular}{|c|c|c|c|c|c|c|c|}
\hline & Local Batak Name & Notes & $\begin{array}{c}\text { Not } \\
\text { weeded }\end{array}$ & $\begin{array}{l}\text { After } \\
1 \text { week }\end{array}$ & $\begin{array}{l}\text { After } \\
2 \text { weeks }\end{array}$ & $\begin{array}{l}\text { After } \\
1 \text { month }\end{array}$ & $\begin{array}{l}\text { After } \\
6 \text { months }\end{array}$ \\
\hline Amaranthus spinosa & Siarum & vegetable & $\mathrm{X}$ & $\mathrm{x}$ & $\mathrm{x}$ & $\mathrm{X}$ & \\
\hline Oxalis corniculata & Si Bitsar & flavoring & $\mathrm{x}$ & $\mathrm{X}$ & $\mathrm{X}$ & $\mathrm{x}$ & \\
\hline Portulaca oleraceae & Beang-beang & $\begin{array}{l}\text { pig food/ } \\
\text { vegetable }\end{array}$ & $\mathrm{x}$ & $\mathrm{x}$ & $\mathrm{x}$ & & \\
\hline Bidens pilosa & Halosi & $\begin{array}{l}\text { livestock } \\
\text { fodder }\end{array}$ & & $\mathrm{x}$ & $\mathrm{X}$ & $\mathrm{X}$ & \\
\hline Cynoglossum L. & Pulut mosi & - & & & $\mathrm{x}$ & $\mathrm{x}$ & \\
\hline $\begin{array}{l}\text { Erechtites valeriani- } \\
\text { folia (Wolf) DC. }\end{array}$ & Mardiruma & pig food & & & $\mathrm{x}$ & $\mathrm{x}$ & $\mathrm{x}$ \\
\hline $\begin{array}{l}\text { Euphorbia prunifolia } \\
\text { Jacq. }\end{array}$ & $\begin{array}{l}\text { Simarlotoplotop } \\
\text { Simargotargotar }\end{array}$ & $\begin{array}{l}\text { livestock } \\
\text { fodder }\end{array}$ & & & $\mathrm{x}$ & $\mathrm{x}$ & \\
\hline $\begin{array}{l}\text { Alternanthera } \\
\text { sessilis (L.) DC. }\end{array}$ & Otok-otok & - & & & & $\mathrm{x}$ & $\mathrm{X}$ \\
\hline Calyptocarpus sp. & Saribungbung & - & & & & $\mathrm{X}$ & $\mathrm{X}$ \\
\hline $\begin{array}{l}\text { Crepis japonica } \\
\text { (L.) Benth. }\end{array}$ & Sakar ni Alum-alum & - & & & & $\mathrm{x}$ & \\
\hline Elsholtzia blanda & Si Tubok ni Arsik & - & & & & $\mathrm{x}$ & \\
\hline Eupatorium sp. & Duhut-duhut merdeka & horse fodder & & & & $\mathrm{x}$ & $\mathrm{X}$ \\
\hline $\begin{array}{l}\text { Lactuca laevigata } \\
\text { (BL.) DC. }\end{array}$ & Alum-alum ri & - & & & & $\mathrm{X}$ & \\
\hline Physalis sp. & $\begin{array}{l}\text { Simarpultakpultak } \\
\text { Goreng-goreng }\end{array}$ & - & & & & $\mathrm{x}$ & $\mathrm{X}$ \\
\hline
\end{tabular}




\begin{tabular}{|c|c|c|c|c|c|c|c|}
\hline & Local Batak Name & Notes & $\begin{array}{c}\text { Not } \\
\text { weeded }\end{array}$ & $\begin{array}{c}\text { After } \\
1 \text { week }\end{array}$ & $\begin{array}{l}\text { After } \\
2 \text { weeks }\end{array}$ & $\begin{array}{l}\text { After } \\
1 \text { month }\end{array}$ & $\begin{array}{l}\text { After } \\
6 \text { months }\end{array}$ \\
\hline Polygala paniculata L. & Simarubanuban & - & & & & $\mathrm{x}$ & $\mathrm{x}$ \\
\hline Ricinus communis & Dulang & - & & & & $\mathrm{x}$ & \\
\hline Solanum nigrum & Lautu & - & & & & $\mathrm{X}$ & \\
\hline $\begin{array}{l}\text { Sonchus asper } \\
\text { (L.) Hill }\end{array}$ & $\begin{array}{l}\text { Hase-hase Debata } \\
\text { Alum-alum } \\
\text { Sakar ni Halimalum } \\
\text { Si Dukkot }\end{array}$ & - & & & & $\mathrm{x}$ & $\mathrm{x}$ \\
\hline $\begin{array}{l}\text { Spilanthes acmella } \\
\text { Auct. non (L.) } \\
\text { or S. paniculata }\end{array}$ & Si Hampir & - & & & & $\mathbf{x}$ & $\mathrm{x}$ \\
\hline Achyranthus asper $\mathrm{L}$. & Si Barani & - & & & & & $\mathrm{x}$ \\
\hline Eleusine indica & Sapadang & $\begin{array}{l}\text { livestock } \\
\text { fodder }\end{array}$ & & & & & $\mathrm{X}$ \\
\hline $\begin{array}{l}\text { Melinis minutiflora } \\
\text { Beauv. }\end{array}$ & $\begin{array}{l}\text { Humbil tuan } \\
\text { Humbil hoda }\end{array}$ & $\begin{array}{l}\text { not eaten } \\
\text { as fodder }\end{array}$ & & & & & $\mathrm{x}$ \\
\hline $\begin{array}{l}\text { Siegesbeckia orien- } \\
\text { talis (L.) }\end{array}$ & $\begin{array}{l}\text { Sakar ni Halimang } \\
\text { Si Hampil }\end{array}$ & - & & & & & $\mathrm{x}$ \\
\hline Urena lobata $\mathrm{L}$. & Sapilulut & - & & & & & $\mathrm{X}$ \\
\hline
\end{tabular}

NOTE: Specimens were collected during the first half of 1978 in newly harvested fields, mostly manured shallot beds, in Huta Ginjang/Sagala (on the northwest side of Mt. Pusuk Buhit, North Sumatra, average altitude $1450 \mathrm{~m}$ ). Identifications of specimens were made by the collector with the aid of Hsuan Keng, Orders and Families of Malayan Seed Plants: Synopsis of Orders and Families of Malayan Gymnosperms, Dicotyledons and Monocotyledons (Kuala Lumpur: University of Malaya Press, 1969), and H. B. Gilliland, Common Malayan Plants, 2nd ed. (Kuala Lumpur: University of Malaya Press, 1962), and with the help of the Staff of the Rijksherbarium, Leiden, The Netherlands. Special thanks are due to Dr. Veldkamp, the grasses expert, and Dr. Backhuizen, cowriter of Flora of Java, who identified the outstanding problem-specimens with dispatch. The specimens listed here, as well as others which do not appear in this succession, are presently housed in the Bailey Hortorium, in Mann Library, Cornell University, Ithaca, N.Y. 